\title{
Transpacific transport of ozone pollution and the effect of recent Asian emission increases on air quality in North America: an integrated analysis using satellite, aircraft, ozonesonde, and surface observations
}

\author{
L. Zhang ${ }^{1}$, D. J. Jacob ${ }^{1,2}$, K. F. Boersma ${ }^{2, *}$, D. A. Jaffe ${ }^{3}$, J. R. Olson ${ }^{4}$, K. W. Bowman ${ }^{5}$, J. R. Worden ${ }^{5}$, \\ A. M. Thompson ${ }^{6}$, M. A. Avery ${ }^{4}$, R. C. Cohen ${ }^{7}$, J. E. Dibb ${ }^{8}$, F. M. Flock ${ }^{9}$, H. E. Fuelberg ${ }^{10}$, L. G. Huey ${ }^{11}$, \\ W. W. McMillan ${ }^{12}$, H. B. Singh ${ }^{13}$, and A. J. Weinheimer ${ }^{14}$ \\ ${ }^{1}$ Department of Earth and Planetary Sciences, Harvard University, Cambridge, MA 02138, USA \\ ${ }^{2}$ School of Engineering and Applied Sciences, Harvard University, Cambridge, MA 02138, USA \\ ${ }^{3}$ University of Washington, 18115 Campus Way NE, Bothell, WA 98021, USA \\ ${ }^{4}$ Atmospheric Sciences Division, Langley Research Center, NASA, Hampton, VA 23681, USA \\ ${ }^{5}$ Jet Propulsion Laboratory, California Institute of Technology, 4800 Oak Grove Drive, Pasadena, CA 91109, USA \\ ${ }^{6}$ The Pennsylvania State University, Department of Meteorology, 503 Walker Building, University Park, \\ PA 16802-5013 USA \\ ${ }^{7}$ Department of Chemistry, University of California, Berkeley, CA 94720, USA \\ ${ }^{8}$ University of New Hampshire, Climate Change Research Center, 39 College Road, Durham, NH 03824, USA \\ ${ }^{9}$ Earth Observing Laboratory, National Center for Atmospheric Research, Boulder, CO 80307, USA \\ ${ }^{10}$ Department of Meteorology, Florida State University, Tallahassee, FL 32306-4520, USA \\ ${ }^{11}$ School of Earth and Atmospheric Sciences, Georgia Institute of Technology, Atlanta, GA 30332-0340, USA \\ ${ }^{12}$ Department of Physics, University of Maryland Baltimore County, 1000 Hilltop Circle, Baltimore, MD 21250, USA \\ ${ }^{13}$ NASA Ames Research Center, MS-245-5, Moffett Field, CA 94035, USA \\ ${ }^{14}$ National Center for Atmospheric Research, 1850 Table Mesa Drive, Boulder, CO 80305, USA \\ *now at: KNMI, PO Box 201, 3730 AE De Bilt, The Netherlands
}

Received: 26 March 2008 - Published in Atmos. Chem. Phys. Discuss.: 24 April 2008

Revised: 1 August 2008 - Accepted: 11 September 2008 - Published: 22 October 2008

\begin{abstract}
We use an ensemble of aircraft, satellite, sonde, and surface observations for April-May 2006 (NASA/INTEX-B aircraft campaign) to better understand the mechanisms for transpacific ozone pollution and its implications for North American air quality. The observations are interpreted with a global 3-D chemical transport model (GEOS-Chem). OMI NO 2 satellite observations constrain Asian anthropogenic $\mathrm{NO}_{\mathrm{x}}$ emissions and indicate a factor of 2 increase from 2000 to 2006 in China. Satellite observations of CO from AIRS and TES indicate two major events of Asian transpacific pollution during INTEX-B. Correlation between TES CO and ozone observations shows evidence
\end{abstract}

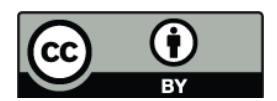

Correspondence to: L. Zhang (linzhang@fas.harvard.edu) for transpacific ozone pollution. The semi-permanent Pacific High and Aleutian Low cause splitting of transpacific pollution plumes over the Northeast Pacific. The northern branch circulates around the Aleutian Low and has little impact on North America. The southern branch circulates around the Pacific High and some of that air impacts western North America. Both aircraft measurements and model results show sustained ozone production driven by peroxyacetylnitrate (PAN) decomposition in the southern branch, roughly doubling the transpacific influence from ozone produced in the Asian boundary layer. Model simulation of ozone observations at Mt. Bachelor Observatory in Oregon $(2.7 \mathrm{~km}$ altitude) indicates a mean Asian ozone pollution contribution of $9 \pm 3$ ppbv to the mean observed concentration of 54 ppbv, reflecting mostly an enhancement in background ozone rather

Published by Copernicus Publications on behalf of the European Geosciences Union. 
than episodic Asian plumes. Asian pollution enhanced surface ozone concentrations by 5-7 ppbv over western North America in spring 2006. The 2000-2006 rise in Asian anthropogenic emissions increased this influence by $1-2 \mathrm{ppbv}$.

\section{Introduction}

Rapid industrial development in eastern Asia and specifically in China has resulted in unprecedented growth in $\mathrm{NO}_{\mathrm{x}}$ emissions with implications for both regional and global tropospheric ozone (Wild and Akimoto, 2001). Efforts to improve US air quality through domestic emission controls could be partly compromised by Asian industrialization and the associated transpacific transport of pollution (Jacob et al., 1999; Fiore et al., 2002). Better understanding the impact of rising Asian $\mathrm{NO}_{\mathrm{x}}$ emissions on transpacific ozone pollution and surface ozone air quality in the United States is therefore of great interest. We address this issue here through a global 3-D model analysis of observations from the NASA Intercontinental Chemical Transport Experiment - Phase B (INTEX-B) aircraft campaign, conducted in spring 2006 over the Northeast Pacific. We integrate into our analysis concurrent measurements from ground sites, sondes, and satellites.

Ozone is produced in the troposphere by the photochemical oxidation of $\mathrm{CO}$ and volatile organic compounds (VOCs) in the presence of nitrogen oxides $\left(\mathrm{NO}_{\mathrm{x}} \equiv \mathrm{NO}+\mathrm{NO}_{2}\right)$. On a global scale, the photochemical production of ozone dominates over the stratospheric influx (Prather and Ehhalt, 2001; Sudo and Akimoto, 2007), and is limited mostly by the supply of $\mathrm{NO}_{\mathrm{x}}$ and methane (Wang et al., 1998b). Anthropogenic sources of $\mathrm{NO}_{\mathrm{x}}$ from combustion combined with the global rise in methane have probably doubled the tropospheric ozone burden in the northern hemisphere over the past century (Prather and Ehhalt, 2001). Ozone has a lifetime of days in the continental boundary layer but weeks in the free troposphere (Jacob et al., 1996; Thompson et al., 1996; Wang et al., 1998b; Fiore et al., 2002), and thus can affect continents downwind.

The dependence of ozone production on $\mathrm{NO}_{\mathrm{x}}$ is highly nonlinear; the ozone production efficiency (OPE) per unit $\mathrm{NO}_{\mathrm{x}}$ consumed increases rapidly as the $\mathrm{NO}_{\mathrm{x}}$ concentration decreases (Liu et al., 1987). Ozone production within the continental boundary layer is relatively inefficient because of the high- $\mathrm{NO}_{\mathrm{x}}$ conditions. A small fraction of emitted $\mathrm{NO}_{\mathrm{x}}$ exported to the free troposphere by frontal lifting, deep convection, or boundary layer venting can lead to disproportionately large ozone production in the free troposphere over the continent and downwind (Jacob et al., 1993; Thompson et al., 1994). The peroxyacetylnitrate (PAN) reservoir for $\mathrm{NO}_{\mathrm{x}}$ can be vented from the boundary layer and transported on a global scale at cold temperatures, eventually decomposing to release $\mathrm{NO}_{\mathrm{x}}$ in the remote troposphere as air masses subside and producing ozone with very high efficiency. Previ- ous studies using aircraft measurements from the PHOBEA, TRACE-P, and ITCT-2K2 campaigns (Kotchenruther et al., 2001; Heald et al., 2003; Hudman et al., 2004) found that PAN decomposition may represent a dominant component of the ozone enhancement in transpacific Asian pollution plumes. The INTEX-B campaign offers far more geographical coverage over the Northeast Pacific and we will see that it enables a better understanding of the mechanisms of ozone production in transpacific plumes.

Asian pollution is typically exported to the Pacific by frontal lifting in warm conveyor belts (WCBs), convection, and orographic lifting (Liu et al., 2003; Brock et al., 2004; Liang et al., 2004; Kiley et al., 2006; Dickerson et al., 2007). It can then be transported across the Pacific in 5-10 days in the free troposphere (Yienger et al., 2000; Jaffe et al., 2001; Stohl et al., 2002). The mean transport time to the surface of western North America is of the order of 2-3 weeks (Liu and Mauzerall, 2005). The transport is most rapid and frequent in spring due to active cyclonic activity and strong westerly winds (Forster et al., 2004; Liang et al., 2004). While Asian plumes with correlated $\mathrm{CO}$ and ozone are often observed in the free troposphere and at mountain sites over the western United States (Price et al., 2004; Jaffe et al., 2005; WeissPenzias et al., 2007), no such plumes are observed at the surface for ozone (Goldstein et al., 2004), presumably because of dilution during entrainment into the boundary layer (Hudman et al., 2004). Asian ozone pollution in US surface air thus mostly reflects an increase in background concentrations (Fiore et al., 2003). Background ozone levels in air entering western North America have increased approximately 10 ppbv between 1984 and 2002 (Jaffe et al., 2003) and ozone concentrations across the western United States show a significant increase with a mean trend of $0.26 \mathrm{ppbva}^{-1}$ (Jaffe and Ray, 2007). The cause for this increase is not clear but rising Asian emissions may be a contributing source.

A unique feature of the INTEX-B campaign was the availability of extensive satellite observations of tropospheric ozone, $\mathrm{NO}_{2}$, and $\mathrm{CO}$ to complement the aircraft observations. Satellites provide a growing resource to quantify emissions of ozone precursors (Martin et al., 2006) and to map the transpacific transport of pollutants (Heald et al., 2003, 2006). They greatly expand the temporal and spatial scale of in situ measurements but are limited in precision, vertical resolution, and the number of species observed. Aircraft vertical profiles during INTEX-B provided validation data for the OMI $\left(\mathrm{NO}_{2}\right)$, AIRS (CO), and TES (ozone, $\mathrm{CO}$ ) satellite sensors (Boersma et al., 2008; Luo et al., 2007b; Richards et al., 2008). Here we use these satellite observations to constrain Asian $\mathrm{NO}_{\mathrm{x}}$ emissions $\left(\mathrm{NO}_{2}\right.$ from $\left.\mathrm{OMI}\right)$, track transpacific plumes ( $\mathrm{CO}$ from AIRS as a long-lived pollution tracer), and observe ozone production in transpacific Asian plumes (ozone and CO from TES). We examine the consistency between the satellite and aircraft information and apply the aircraft data to further analysis of plume chemistry. We also use sonde data from INTEX Ozonesonde Network 
Study (IONS) (Thompson et al., 2008) to test model results, and use ground-based measurements at Mount Bachelor Observatory in central Oregon (Jaffe et al., 2005; Reidmiller et al., 2008) to link observed Asian pollution influences in the free troposphere to North American surface air quality.

\section{Observations and model}

\subsection{In-situ measurements}

The NASA INTEX-B aircraft mission took place from 17 April to 15 May 2006 over the Northeast Pacific and the west coast of North America (Singh et al., 2008 ${ }^{1}$ ). It used the NASA DC-8 (ceiling $12 \mathrm{~km}$ ) as its primary platform operating out of Honolulu and Anchorage, complemented with the NSF/NCAR C-130 (ceiling $7 \mathrm{~km}$ ) operating out of Seattle. Figure 1 shows the flights tracks of the DC- 8 and C130 aircraft. These included extensive vertical profiling on all flights. The DC-8 conducted 10 science flights of about 9-h duration each, with large latitudinal coverage over the Northeast Pacific. The C-130 conducted 12 science flights of about 8-h duration each off and over the US Northwest Coast. Quasi-Lagrangian sampling studies were performed between the DC-8 and the C-130 to track the chemical evolution of Asian pollution plumes (Latto and Fuelberg, 2007).

Details of the chemical payload on both aircraft are given by Singh et al. (in preparation). We principally make use here of the 1-min average measurements of ozone, $\mathrm{CO}, \mathrm{NO}$, $\mathrm{NO}_{2}, \mathrm{PAN}, \mathrm{OH}$, and $\mathrm{HO}_{2}$. Intercomparisons between the two aircraft show excellent agreement for ozone, $\mathrm{CO}$, and $\mathrm{NO}_{\mathrm{x}}$, but for PAN the correlation is poor and C-130 measurements are $23 \%$ higher than DC- 8 on average as discussed in Chen et al. (2007).

Additional in situ data for the INTEX-B period analyzed in our study include ozonesonde observations at Trinidad Head (California) and Richland (Washington) made during the IONS-06 collaborative field campaign (Thompson et al., 2008; http://croc.gsfc.nasa.gov/intexb/ions06.html), and surface measurements at Mount Bachelor Observatory (MBO, $44.0^{\circ} \mathrm{N}, 121.7^{\circ} \mathrm{W}, 2.7 \mathrm{~km}$ altitude in Oregon) (Wolfe et al., 2007; Reidmiller et al., 2008).

\subsection{Satellites}

We use satellite observations from OMI and TES aboard Aura and AIRS aboard Aqua. Aura was launched in July 2004 into a polar, sun-synchronous orbit with ascending equator crossing around 1345 local time. The Ozone Monitoring Instrument (OMI) is a nadir-scanning instrument

\footnotetext{
${ }^{1}$ Singh, H. B., Brune, W. H., Crawford, J. H., Jacob, D. J., Russell, P. B., et al.: Chemistry and Transport of Pollution over the Gulf of Mexico and the Pacific: Spring 2006 INTEX-B Campaign Overview and First Results, Atmos. Chem. Phys., submitted, 2008.
}

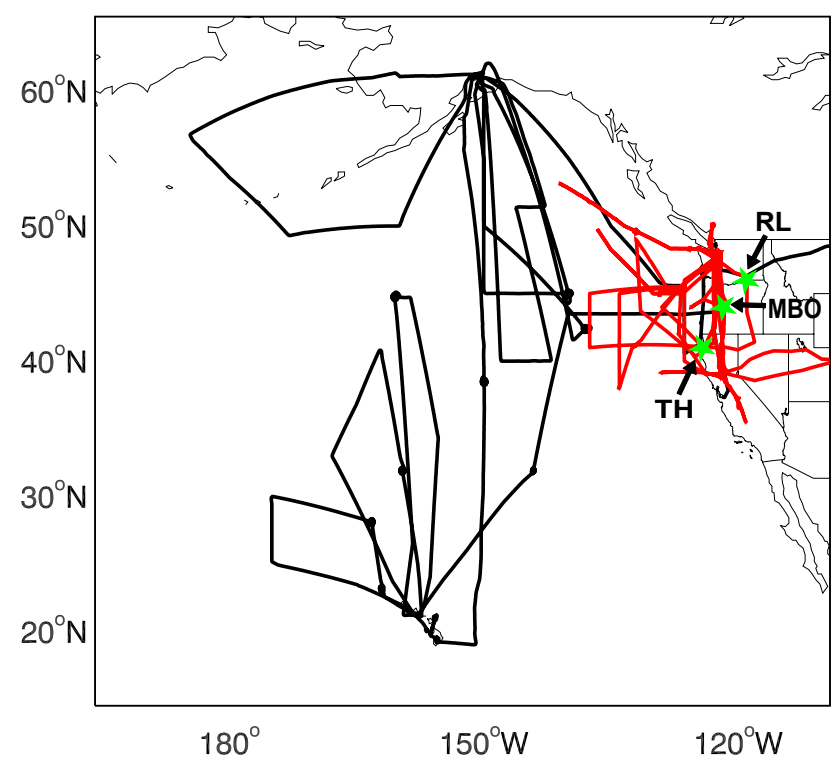

Fig. 1. Flight tracks of the NASA DC-8 (black) and NSF/NCAR C130 (red) aircraft during the INTEX-B campaign (17 April-15 May 2006). The green stars show the locations of the Mt. Bachelor Observatory (MBO) in Oregon (2.7 km altitude), Trinidad Head (TH) in California, and Richland (RL) in Washington.

which measures backscattered solar radiation over the 270$500 \mathrm{~nm}$ wavelength range with a spectral resolution of $0.42-$ $0.63 \mathrm{~nm}$ (Levelt et al., 2006). It has a spatial resolution of $13 \times 24 \mathrm{~km}^{2}$ at nadir and daily global coverage. We use here near-real time (NRT) tropospheric $\mathrm{NO}_{2}$ columns retrieved by KNMI/NASA (Boersma et al., 2007). This product was successfully validated with $\mathrm{DC}-8 \mathrm{NO}_{2}$ vertical profiles (Boersma et al., 2008).

The Tropospheric Emission Spectrometer (TES) is a Fourier transform IR emission spectrometer with high spectral resolution $\left(0.1 \mathrm{~cm}^{-1}\right.$ apodized $)$ and a wide spectral range $\left(650-3050 \mathrm{~cm}^{-1}\right)$, enabling retrieval of both tropospheric ozone and $\mathrm{CO}$ in the nadir based on optimal estimation techniques (Beer et al., 2006; Bowman et al., 2006). Joint retrieval of ozone and CO enables TES to diagnose ozone pollution influences through $\mathrm{O}_{3}$-CO correlations (Zhang et al., 2006). During INTEX-B, TES alternated daily between "global survey" and "step-and-stare" observational modes. The standard products ("global surveys") consist of 16 daily orbits across the North Pacific with retrievals spaced $1.6^{\circ}$ along the orbit track. The "step-and-stare" observations have denser nadir coverage along the orbit track over the North Pacific. Vertical profiles retrieved from TES provide 1-2 degrees of freedom for signal (DOFS) for ozone in the troposphere corresponding to about $6 \mathrm{~km}$ vertical resolution, and about 1 DOFS for CO weighted towards the middle troposphere (Worden et al., 2004). We use V002 of TES data. Validation with ozonesondes and INTEX-B aircraft data shows that TES ozone profiles are biased high by $3-10$ ppbv (Nassar 
et al., 2008; Richards et al., 2008). TES CO measurements are consistent with those from MOPITT (Luo et al., 2007a) and within $\pm 15 \%$ of the INTEX-B aircraft data (Luo et al., 2007b). We filter out retrievals with poor sensitivity (diagonal term of the averaging kernel matrix at $681 \mathrm{hPa}<0.01$, corresponding to $<0.25$ DOFS (Luo et al., 2007a)). To ensure that our conclusions are not affected by the variable a priori used to regularize the TES retrievals, we reprocess the TES profiles using a fixed a priori following Zhang et al. (2006).

The Atmospheric Infrared Sounder (AIRS) was launched on the NASA Aqua satellite in May 2002. It is a cross-track scanning grating spectrometer covering the 3.7 to $16 \mu \mathrm{m}$ spectral range with 2378 channels (Aumann et al., 2003). AIRS has a spatial resolution of $45 \mathrm{~km}$ at nadir and a $1650 \mathrm{~km}$ cross-track swath, enabling daily global coverage. $\mathrm{CO}$ retrievals are obtained at $4.7 \mu \mathrm{m}$ including for partly cloudy scenes (McMillan et al., 2005). We use version 4.2 of AIRS $\mathrm{CO}$ retrievals (McMillan et al., 2008). AIRS shows a positive bias of 15-20 ppbv relative to MOPITT over the oceans (Warner et al., 2007). Here we use AIRS observations of CO column qualitatively due to lack of well-defined averaging kernels in version 4.2.

\subsection{Model description}

We use the GEOS-Chem global 3-D model of tropospheric chemistry (v7-04-09; http://www.as.harvard.edu/chemistry/ trop/geos/) driven by GEOS-4 assimilated meteorological observations from the NASA Global Modeling and Assimilation Office (GMAO). The model is applied to a global simulation of ozone- $\mathrm{NO}_{\mathrm{x}}$-VOC-aerosol chemistry. General descriptions of GEOS-Chem are given by Bey et al. (2001) and Park et al. (2004), and previous applications to transpacific ozone chemistry include studies by Fiore et al. (2002), Jaeglé et al. (2003), Weiss-Penzias et al. (2004), Bertschi et al. (2004), Goldstein et al. (2004), Hudman et al. (2004), and Liang et al. (2007).

Meteorological fields in the GEOS-4 data have a temporal resolution of $6 \mathrm{~h}$ ( $3 \mathrm{~h}$ for surface variables and mixing depths) and a horizontal resolution of $1^{\circ}$ latitude by $1.25^{\circ}$ longitude, with 55 levels in the vertical. We degrade the horizontal resolution to $2^{\circ}$ latitude by $2.5^{\circ}$ longitude for input to GEOSChem. The simulations are conducted for April-May 2006 at $2^{\circ} \times 2.5^{\circ}$ resolution. They are initialized on 1 April 2006 with GEOS-Chem fields generated by an 8 -month spin-up simulation with $4^{\circ} \times 5^{\circ}$ resolution.

Zhang et al. $^{2}$ (http://www.cgrer.uiowa.edu/EMISSION_ DATA_new/index_16.html) compiled a detailed anthropogenic emission inventory for Asia $\left(8^{\circ} \mathrm{N}-50^{\circ} \mathrm{N}, 80^{\circ} \mathrm{E}-\right.$ $150^{\circ} \mathrm{E}$ ) for the spring 2006 period of INTEX-B (hereafter

\footnotetext{
${ }^{2}$ Zhang, Q., Streets, D. G., He, K., et al.: A new inventory of anthropogenic emissions in Asia for the year 2005/2006, Atmos. Chem. Phys., manuscript in preparation, 2008.
}

referred to as S2006). We use their emission estimates except for $\mathrm{NO}_{\mathrm{x}}$ which we derive instead from OMI $\mathrm{NO}_{2}$ data as a better estimate (Sect. 3). For US anthropogenic emissions we use the National Emission Inventory for 1999 (NEI 99) from the US Environmental Protection Agency (EPA) (http://www.epa.gov/ttn/chief/net/). For the rest of the world we use anthropogenic emissions from the Global Emission Inventory Activity (GEIA), scaled to 1998 on the basis of national energy statistics as described by Bey et al. (2001).

Streets et al. (2003) previously reported an anthropogenic emission inventory for Asia in 2000 (hereafter referred to as S2000), and we will use that inventory in a sensitivity simulation to assess the impact of rising Asian emissions from 2000 to 2006. For the same Asian region, the S2006 inventory is $41 \%$ higher for $\mathrm{CO}, 45 \%$ higher for non-methane VOCs (NMVOCs), and 65\% higher for $\mathrm{NO}_{\mathrm{x}}$. Our $\mathrm{NO}_{\mathrm{x}}$ source constrained by the $\mathrm{OMI} \mathrm{NO}_{2}$ observations is 2 times higher than S2000. Some of the change in the CO inventory in S2006 relative to S2000 reflects an underestimate in the original inventory (Streets et al., 2006), in addition to emission growth. The increase in NMVOCs reflects emission growth and is consistent with Ohara et al. (2007). The increase in $\mathrm{NO}_{\mathrm{x}}$ also mainly reflects emission growth, as will be discussed in Sect. 3.

Biomass burning emissions are from a monthly climatological inventory (Duncan et al., 2003). Fire emissions over Southeast Asia in 2006 were not unusual compared with previous years (van der Werf et al., 2006; http://ess1. ess.uci.edu/ jranders). Soil $\mathrm{NO}_{\mathrm{x}}$ emissions are computed using a modified version of the algorithm by Yienger and Levy (1995) with canopy reduction factors described by Wang et al. (1998a). Emissions of $\mathrm{NO}_{\mathrm{x}}$ from lightning are linked to deep convection following the parameterization of Price and Rind (1992) with vertical profiles taken from Pickering et al. (1998). Following the suggestions by Martin et al. (2006) and Hudman et al. (2007) and evidence from observations (Huntrieser et al., 2006), we use a $\mathrm{NO}_{\mathrm{x}}$ yield per flash of 125 moles in the tropics and 500 moles at northern mid-latitudes (north of $30^{\circ} \mathrm{N}$ ). The resulting lightning source is $6 \mathrm{Tg} \mathrm{N} \mathrm{a}^{-1}$ globally including $1.6 \mathrm{Tg} \mathrm{N} \mathrm{a}^{-1}$ north of $30^{\circ} \mathrm{N}$. Transport of ozone from the stratosphere is simulated using the "Synoz" boundary condition of McLinden et al. (2000), which imposes a global cross-tropopause ozone flux of approximately $495 \mathrm{Tg}$ ozone $\mathrm{a}^{-1}$ transported downward by the model.

We present results from three full-chemistry simulations: (1) the standard simulation for 2006 as described above; (2) a sensitivity simulation without Asian $\left(8^{\circ}-50^{\circ} \mathrm{N}, 80^{\circ}-150^{\circ} \mathrm{E}\right)$ anthropogenic emissions (fossil fuel+biofuel), which allows us to derive Asian pollution enhancements in the standard simulation by difference; and (3) a sensitivity simulation for 2000 using S2000 Asian emissions from Streets et al. (2003) to derive the effect of 2000-2006 regional growth in emissions. We also conduct single-tracer simulations of odd oxygen $\left(\mathrm{O}_{x} \equiv \mathrm{O}_{3}+\mathrm{NO}_{2}+2 \mathrm{NO}_{3}+3 \mathrm{~N}_{2} \mathrm{O}_{5}+\mathrm{HNO}_{3}+\mathrm{HNO}_{4}+\right.$ 


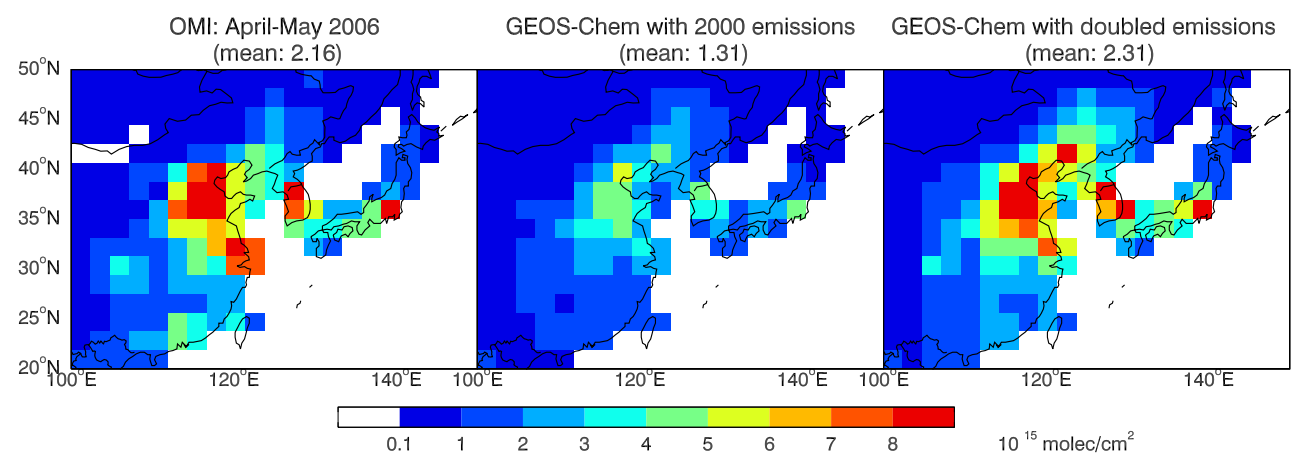

Fig. 2. Mean tropospheric $\mathrm{NO}_{2}$ columns from OMI and the GEOS-Chem model in April-May 2006 over eastern Asia. The OMI data (left panel) have been mapped on the $2^{\circ} \times 2.5^{\circ}$ GEOS-Chem grid. GEOS-Chem model results are shown using 2000 anthropogenic $\mathrm{NO}_{\mathrm{x}}$ emissions from Streets et al. (2003) (central panel) and a doubling of these emissions to represent 2006 conditions (right panel). The numbers in parentheses are the mean column values over eastern Asia.

peroxyacylnitrates), using archived 3-D fields of daily production rates and loss frequencies from the above simulations. This ozone tracer technique has been applied in a number of model studies to track the transport and fate of ozone produced in different regions (Wang et al., 1998b; Li et al., 2002; Sudo and Akimoto, 2007). We use it here to assess the relative contributions to transpacific ozone pollution from ozone produced in the Asian boundary layer versus formed downwind of Asia following $\mathrm{NO}_{\mathrm{x}}$ and PAN export.

\section{Constraints on Asian anthropogenic $\mathrm{NO}_{\mathrm{x}}$ emissions}

The bottom-up combustion inventories for developing countries such as China are subject to large errors in available energy statistics and emission factors (Streets et al., 2003). We use here OMI tropospheric $\mathrm{NO}_{2}$ columns to provide top-down constraints on surface $\mathrm{NO}_{\mathrm{x}}$ emissions for AprilMay 2006 over eastern Asia $\left(20-50^{\circ} \mathrm{N}, 100-150^{\circ} \mathrm{E}\right)$ including East China, Japan, and Korea. Following Martin et al. (2003), we determine local top-down surface $\mathrm{NO}_{\mathrm{x}}$ emissions from the OMI $\mathrm{NO}_{2}$ columns by applying the GEOSChem relationship between $\mathrm{NO}_{2}$ columns and local emissions derived from the bottom-up inventory and sampled close to the satellite overpass time. We adopt the improvement from Wang et al. (2007) by accounting for contributions from external and non-surface sources, including in particular lightning and biomass burning in Southeast Asia. Contributions from these sources to tropospheric $\mathrm{NO}_{2}$ columns over eastern Asia were identified by GEOS-Chem sensitivity simulations with anthropogenic emissions over eastern Asia shut off. They typically represent $10-20 \%$.

Figure 2 shows the $\mathrm{NO}_{2}$ tropospheric columns observed by OMI (left panel) vs. simulated by GEOS-Chem using S2000 anthropogenic $\mathrm{NO}_{\mathrm{x}}$ emissions from Streets et al. (2003) (central panel) at the satellite overpass time. The model is $40 \%$ too low. We can match the OMI data by doubling the S2000 anthropogenic $\mathrm{NO}_{\mathrm{x}}$ emissions over eastern Asia (including China, Japan, and Korea), as shown in the right panel. This yields a high spatial correlation with OMI observations $\left(\mathrm{r}=0.92, \mathrm{n}=209\right.$ on the $2^{\circ} \times 2.5^{\circ}$ grid $)$ as well as negligible bias (slope of 0.94 for the reduced-major-axis regression line). Walker et al. ${ }^{3}$ obtained a similar constraint on Asian $\mathrm{NO}_{\mathrm{x}}$ emissions using SCIAMACHY satellite $\mathrm{NO}_{2}$ data.

Our factor of 2 correction to the S2000 inventory likely reflects actual 2000-2006 emission growth in China and underestimation of bottom-up estimates for Japan and Korea. The S2006 bottom-up inventory (Zhang et al., in preparation) for the INTEX-B period shows a 98\% growth of $\mathrm{NO}_{\mathrm{x}}$ anthropogenic emissions from China relative to S2000, in close agreement with our results. Wang et al. (2007) previously found the S2000 inventory to be $15 \%$ lower than contemporary top-down constraints from the GOME $\mathrm{NO}_{2}$ satellite instrument. It thus appears that Chinese anthropogenic $\mathrm{NO}_{\mathrm{x}}$ emissions have indeed doubled from 2000 to 2006. Previous trend analyses of Chinese anthropogenic $\mathrm{NO}_{\mathrm{x}}$ emissions for the 1996-2004 period indicated an accelerating growth rate, with total growth for that period of $61 \%$ in the bottom-up inventory (Zhang et al., 2007) and 95\% from satellite data (van der A et al., 2006).

The top-down constraints from OMI also imply factor of 2 increases in Japan and South Korean emissions relative to the S2000 inventory. However, S2006 report no significant 2000-2006 emission changes in these regions. Bottom-up and top-down analyses for earlier periods also show little trend (Richter et al., 2005; Ohara et al., 2007). The correction to the S2000 inventory in Japan and Korea needed to match the OMI data in Fig. 2 thus appears to reflect an underestimate in the inventory rather than an actual 2000-2006 emission trend. Jaeglé et al. (2005) and Wang et al. (2007)

\footnotetext{
${ }^{3}$ Walker, T. W., Martin, R. V., van Donkelaar, A., et al.: TransPacific transport of reactive nitrogen and ozone during spring, manuscript in preparation, 2008.
} 

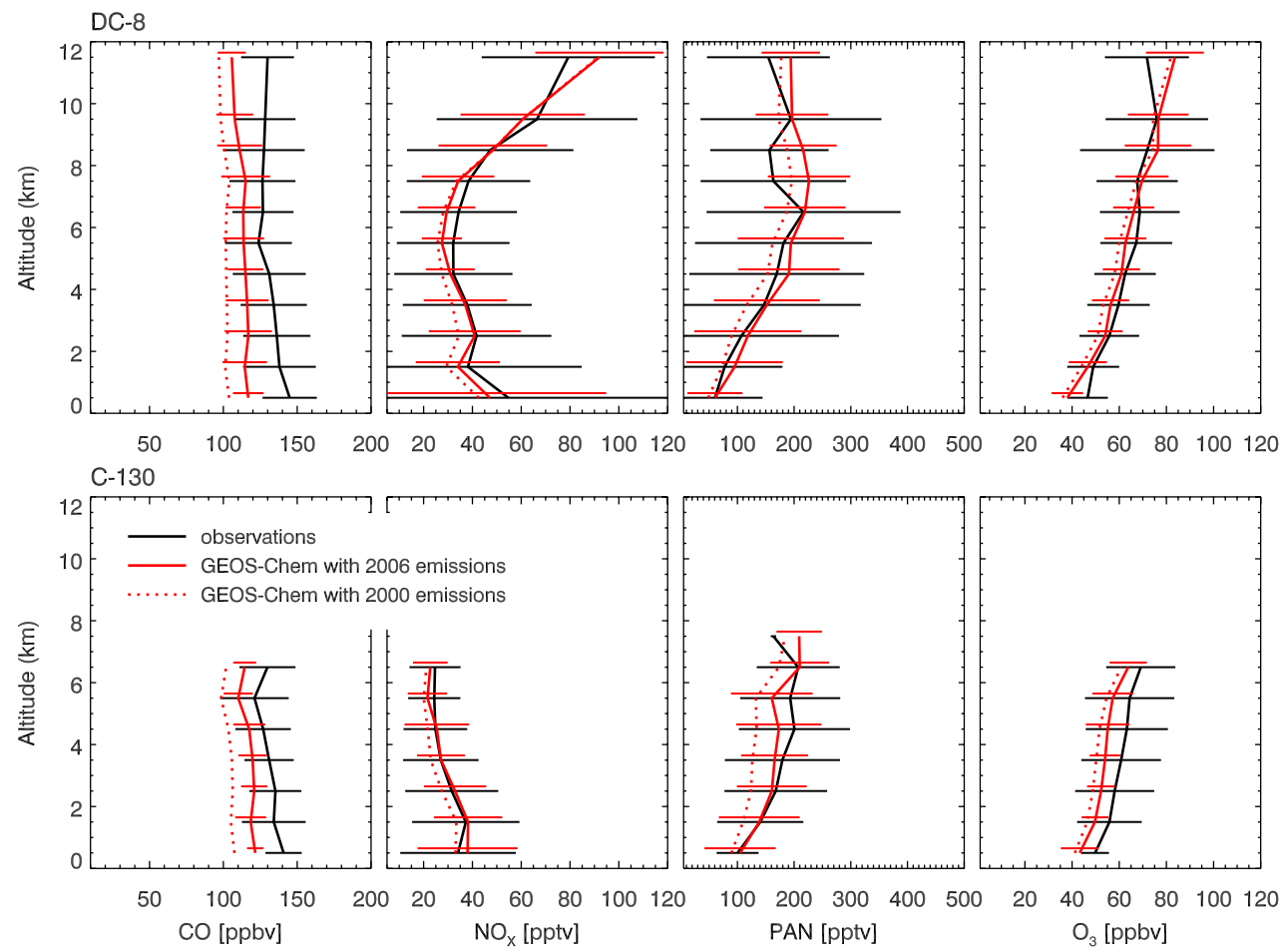

Fig. 3. Mean vertical profiles of $\mathrm{CO}, \mathrm{NO}_{\mathrm{x}}$, PAN, and $\mathrm{O}_{3}$ concentrations over the Northeast Pacific during INTEX-B (April-May 2006). Observations (black) from the DC-8 (top) and C-130 (bottom) aircraft are compared to GEOS-Chem model results with 2006 Asian emissions (red solid) and 2000 Asian emissions (red dash). Horizontal bars are standard deviations. Here and in subsequent figures, the observations have been filtered to remove urban plumes, biomass burning plumes, and stratospheric air as described in the text. Model results are sampled along the flight tracks at the time of the flights, and observations are averaged over the model grid.

previously indicated a $30 \%-50 \%$ underestimate in the $\mathrm{S} 2000$ inventory relative to GOME $\mathrm{NO}_{2}$ observations over Japan.

In what follows, we will interpret the doubling of anthropogenic $\mathrm{NO}_{\mathrm{x}}$ emissions in eastern Asia relative to $\mathrm{S} 2000$ as representing the actual 2000-2006 regional growth rate in emissions. This interpretation overestimates the actual growth by about $30 \%$ due to the apparent underestimation in S2000 for Japan and Korea. In any case, our standard simulation for 2006 includes our best estimate of East Asian emissions for that year constrained by the OMI data.

\section{Mean vertical profiles}

We compare in Fig. 3 the observed and simulated mean vertical distributions of $\mathrm{CO}, \mathrm{NO}_{\mathrm{x}}, \mathrm{PAN}$, and ozone concentrations for the ensemble of DC-8 and C-130 flights in Fig. 1. Model results are sampled along the flight tracks at the time of flights. Observations are gridded to model resolution. The comparison excludes urban plumes observed during takeoff and landing as diagnosed by $\mathrm{NO}_{2}>500$ pptv and altitude $<3 \mathrm{~km}$; biomass burning plumes as diagnosed by $\mathrm{HCN}$ $>500$ pptv or $\mathrm{CH}_{3} \mathrm{CN}>225$ pptv; and stratospheric air as diagnosed by $\mathrm{O}_{3} / \mathrm{CO}>1.25 \mathrm{~mol} \mathrm{~mol}^{-1}$. These filters exclude $1 \%, 4 \%$ (urban plumes); $5 \%, 4 \%$ (biomass burning plumes); and 7\%, 0\% (stratospheric air) of the data for the DC- 8 and C-130, respectively. The stratospheric filter does not exclude stratospheric influence within the troposphere, as mixing of stratospheric and tropospheric air masses causes the $\mathrm{O}_{3} / \mathrm{CO}$ ratio to drop rapidly below the filter threshold.

CO profiles show little mean vertical structure. Modeled $\mathrm{CO}$ is $15 \%$ lower than observations, consistent with an $\mathrm{OH}$ overestimate in the model. Figure 4 shows the mean simulated vs. observed vertical distributions of $\mathrm{OH}$ and $\mathrm{HO}_{2}$ concentrations. The model is too high for $\mathrm{OH}$ by $27 \%$ on average in the DC- 8 data and by a comparable factor in the C-130 data. In contrast there is no significant bias for $\mathrm{HO}_{2}$. Ren et al. (2007) found that the $\mathrm{OH}$ and $\mathrm{HO}_{2}$ observations from the DC-8 aircraft are within $15 \%$ of calculations from the NASA Langley photochemical box model (Olson et al. 2006) constrained with the ensemble of concurrent aircraft observations. To investigate this discrepancy, we conducted a test where we constrained the NASA Langley box model with GEOS-Chem output rather than observations from the DC-8 aircraft. This closely reproduced the $\mathrm{OH}$ and $\mathrm{HO}_{2}$ concentrations simulated by GEOS-Chem, indicating that differences in chemical mechanisms are not responsible for the discrepancy. It appears instead that the discrepancy is mostly caused by an overestimate of water vapor in the GEOS-4 data set and 
upper tropospheric NO concentrations in GEOS-Chem relative to the observations.

Observations of $\mathrm{NO}$ and $\mathrm{NO}_{2}$ from both the DC-8 and the $\mathrm{C}-130$ are in photostationary state and the absolute values are in agreement with the GEOS-Chem simulation at low altitude (below $6 \mathrm{~km}$ for the DC- 8 and below $4 \mathrm{~km}$ for the C130). At higher altitudes the $\mathrm{NO} / \mathrm{NO}_{2}$ ratio from both platforms is inconsistent with the assumption of photostationary state. Differences for the C-130 data are within the uncertainty in the instrument zero offsets $(<5 \mathrm{pptv})$. For the DC-8 the differences become larger than that can be explained as uncertainties in the measurements above $8 \mathrm{~km}$. The GEOSChem model overestimates NO measurements from DC-8 by $50 \%$ at $10 \mathrm{~km}$ (60 vs. $40 \mathrm{pptv})$ and underestimates $\mathrm{NO}_{2}$ at the same altitude by a factor of $2(20$ vs. 40 pptv). By coincidence $\mathrm{NO}_{\mathrm{x}}$ is in agreement. If we attribute all of the error to one or the other measurement, then the GEOS-Chem model predicts either $50 \%$ too much $\mathrm{NO}_{\mathrm{x}}$ or $100 \%$ too little at $10 \mathrm{~km}$. Here and in what follows we use total $\mathrm{NO}_{\mathrm{x}}$ as the comparison metric.

Comparisons of simulated and observed $\mathrm{NO}_{\mathrm{x}}$ and PAN in Fig. 3 show a low bias in the model with 2000 Asian emissions, which largely disappears in the model with 2006 Asian emissions. The doubling of anthropogenic $\mathrm{NO}_{\mathrm{x}}$ emissions over eastern Asia from 2000 to 2006 increases $\mathrm{NO}_{\mathrm{x}}$ concentrations by 3 pptv over the Northeast Pacific in the model. The PAN simulation with 2006 Asian emissions shows a $14 \%$ overestimate relative to the DC- 8 observations while a $6 \%$ underestimate relative to $\mathrm{C}-130$ observations, consistent with the $23 \%$ systematic difference in PAN measurements between the two aircraft (Chen et al., 2007). The 2000-2006 rise in Asian anthropogenic emissions increases the mean simulated PAN concentrations by $26 \mathrm{pptv}(21 \%)$. Jaffe et al. (2007) compared the INTEX-B C-130 aircraft observations of $\mathrm{NO}_{\mathrm{x}}$ and PAN to their previous observations from the PHOBEA aircraft campaign in 1999 over the Northwest Coast of the United States, and found no significant change in $\mathrm{NO}_{\mathrm{x}}$ but a $22 \%$ mean increase in PAN.

Model results for ozone in Fig. 3 show a 3 ppbv mean increase from the 2000-2006 rise in Asian anthropogenic emissions. The model result with 2006 Asian emissions is consistent with DC-8 measurements. Comparison with C130 measurements shows a negative bias of 5 ppbv. The DC-8 aircraft covered a large region over the Northeast $\mathrm{Pa}-$ cific, while the C-130 flew over the North American West Coast (Fig. 1), where stratospheric influence on ozone is particularly strong in spring (Cooper et al., 2004). Hudman et al. (2004) previously found that GEOS-Chem underestimated observed ozone concentrations from the ITCT 2K2 campaign over California in April-May 2002 by up to $10 \mathrm{ppbv}$ due to its failure to reproduce high-ozone layers of stratospheric origin.

We further compared model results with sonde measurements from IONS-06. Figure 5 shows the comparison with the mean ozonesonde profiles at Trinidad Head on the
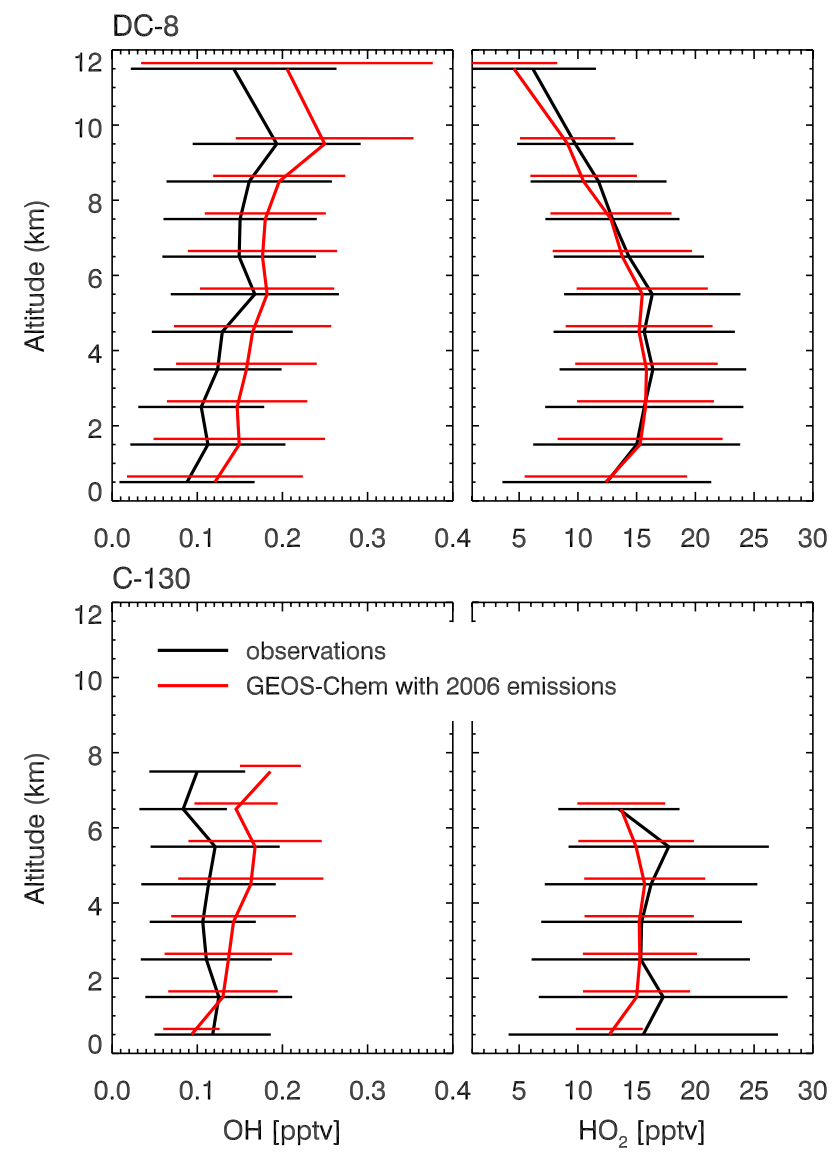

Fig. 4. Same as Fig. 3 but for $\mathrm{OH}$ and $\mathrm{HO}_{2}$. Only model results with 2006 Asian emissions are shown.

northern California coast $\left(41^{\circ} \mathrm{N}, 124^{\circ} \mathrm{W}\right)$ and Richland in Washington $\left(46^{\circ} \mathrm{N}, 119^{\circ} \mathrm{W}\right)$ during the INTEX-B period. The model reproduces the mean observed ozone profile at Trinidad Head but is $5 \mathrm{ppbv}$ too low at $2-5 \mathrm{~km}$. At Richland where stratospheric influences are more pronounced, the model is $10 \mathrm{ppbv}$ too low in the free troposphere. Similar GEOS-Chem underestimate of the ozonesonde observations at Trinidad Head was reported by Hudman et al. (2004) for the ITCT-2K2 aircraft campaign.

\section{Satellite and aircraft observations of transpacific transport}

\subsection{Transpacific transport as seen from satellites}

Figure 6 shows AIRS (CO) and TES (CO, ozone) time series for the INTEX-B period over the Northwest and Northeast Pacific. AIRS has daily global coverage while TES is much sparser. AIRS observations of CO column over the Northwest Pacific show Asian outflow events every 3-6 days. These outflow events are associated with the passage of cold fronts across the Asian Pacific Rim (Liu et al., 2003; Heald 

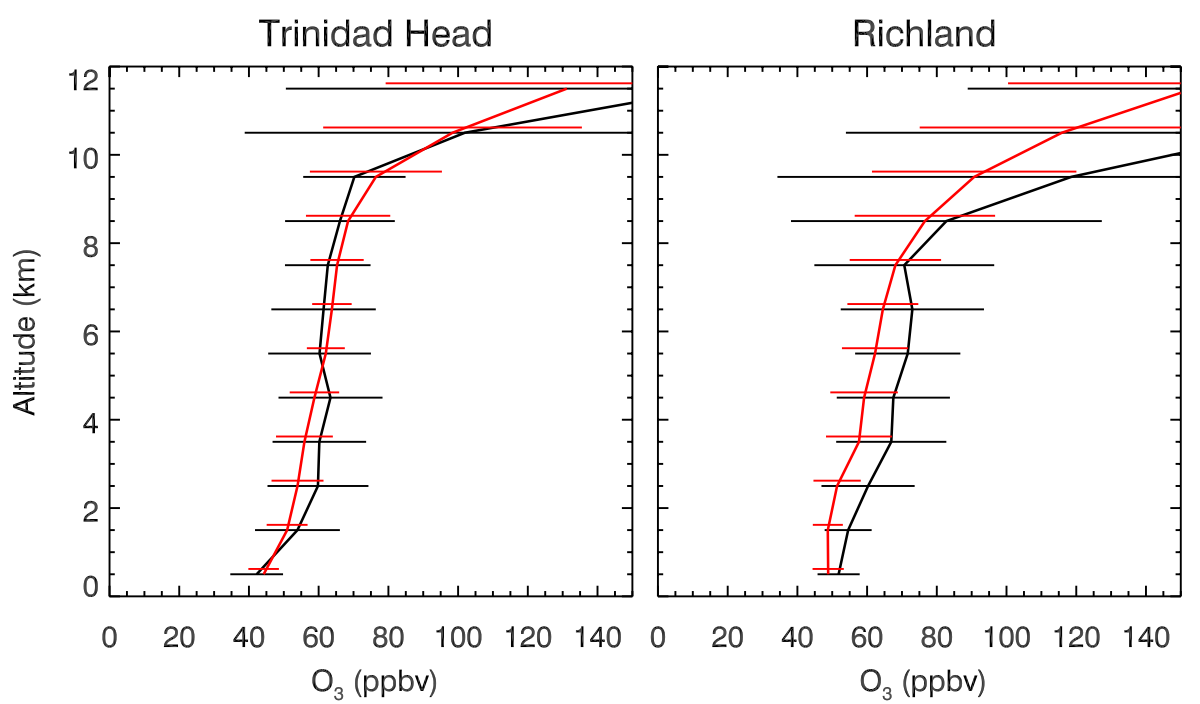

Fig. 5. Mean ozone concentration profiles over Trinidad Head, California $\left(41^{\circ} \mathrm{N}, 124^{\circ} \mathrm{W}\right)$ and Richland, Washington $\left(46^{\circ} \mathrm{N}, 119^{\circ} \mathrm{W}\right)$ during the INTEX-B campaign. The black lines show the means and standard deviations of ozonesonde data for the period of 17 April-15 May 2006 (13 sondes at Trinidad Head and 24 at Richland). The red lines show the corresponding means and standard deviations of model results with 2006 Asian emissions.

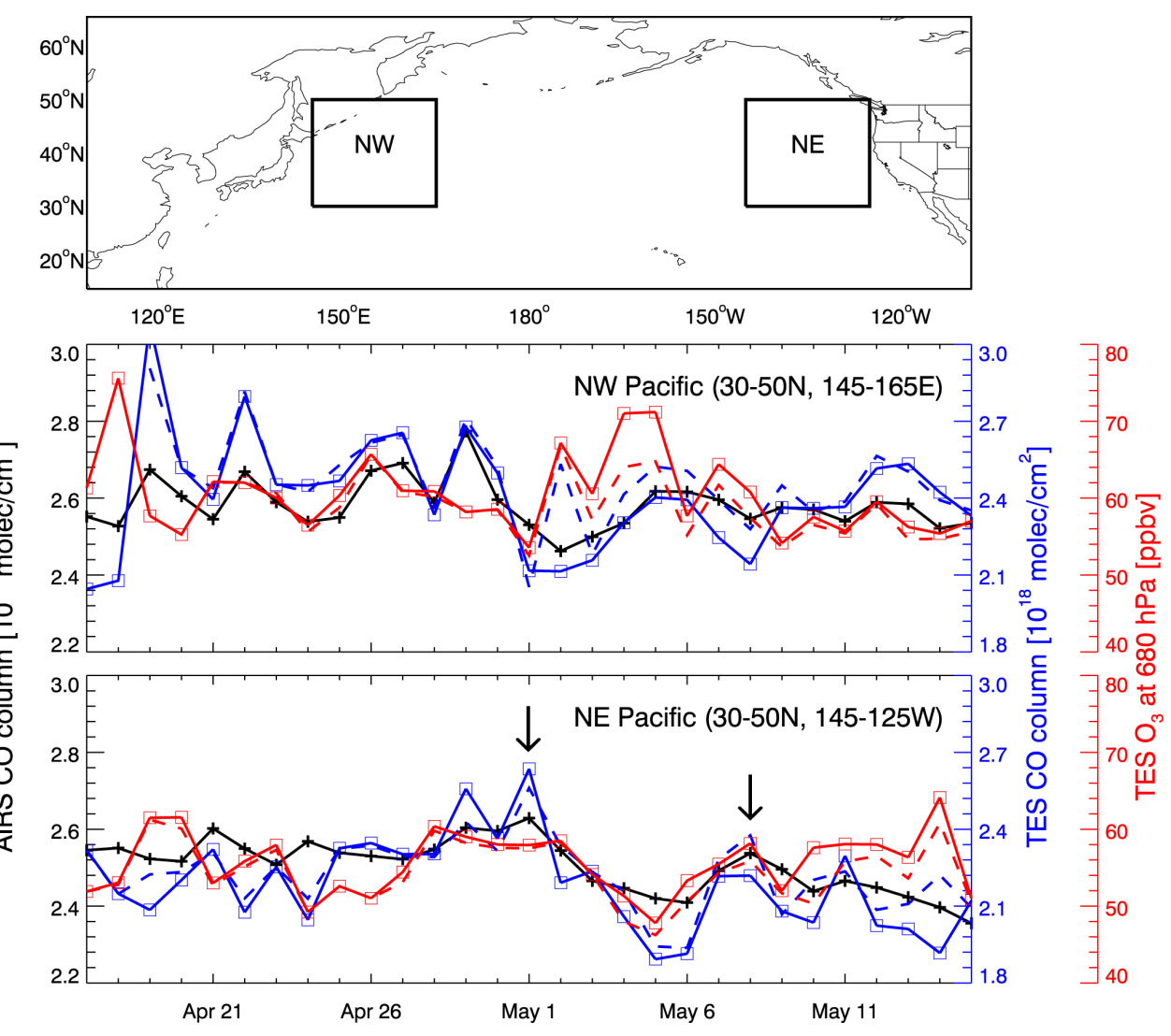

Fig. 6. Time series of AIRS and TES CO columns, and TES ozone at $680 \mathrm{hPa}$ over the Northwest and Northeast Pacific during the INTEX-B time period. Two transpacific transport events are identified by arrows, reaching the Northeast Pacific on 1 and 8 May. The dashed lines show the time series of TES observations after filtering out stratospheric influence as described in the text. 


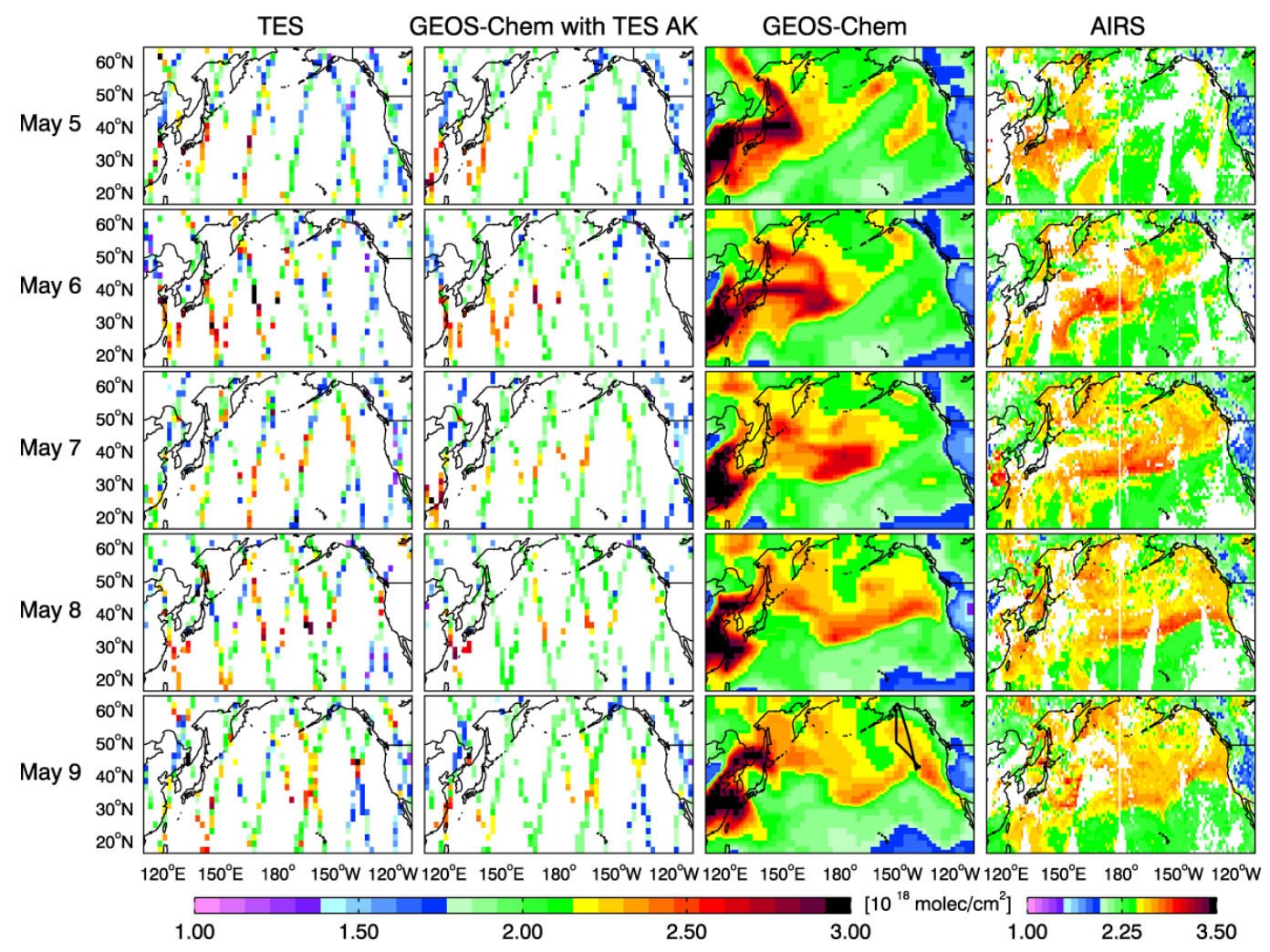

Fig. 7. CO columns from AIRS, TES and the GEOS-Chem model during the 5-9 May transpacific Asian pollution event observed by the INTEX-B aircraft. GEOS-Chem values are sampled along the TES orbit tracks and with TES averaging kernels (AK) applied. The original TES data have been reprocessed to remove the effect of variable a priori and averaged on the model resolution. GEOS-Chem columns sampled at 12:00 UT without averaging kernels applied are also shown; the black line in the lower panel shows the INTEX-B DC-8 flight track on 9 May.

et al., 2003). CO shows a decreasing trend from April to May over the Northeast Pacific due to the seasonal decline of biomass burning in Southeast Asia (Duncan et al., 2003) and the seasonal increase of $\mathrm{OH}$ concentrations. The $\mathrm{CO}$ column data over the Northeast Pacific identify two major events of transpacific transport of Asian pollution during the INTEX$\mathrm{B}$ period. The two events were also seen by in situ observations. Event 1 was observed from the C-130 on 1 May (Barletta et al., 2007), and was also observed at the MBO site as shown in Sect. 7.1. Event 2 was observed from the DC-8 on 9 May as discussed in Sect. 5.2, and arrived at MBO around 10 May.

TES observations of CO column show similar temporal variation as AIRS ( $\mathrm{r}=0.75$ for both regions) but with larger variability. Figure 6 also shows TES observations of ozone concentrations retrieved at $680 \mathrm{hPa}$ (corresponding to a broad mid-troposphere weighting function). The time series of TES $\mathrm{CO}$ and ozone observations are not always correlated. There are some periods with high ozone but low $\mathrm{CO}$, such as 2 May over the Northwest Pacific and 14 May over the Northeast Pacific. Stratospheric intrusions occur ubiquitously throughout the midlaitudes (Cooper et al., 2004), and mixing Asian pollution plumes with stratospheric air masses obfuscates the $\mathrm{O}_{3}$-CO correlations (Nowak et al., 2004). After filtering out TES observations with stratospheric influence as diagnosed by TES $\mathrm{O}_{3} / \mathrm{CO}$ at $680 \mathrm{hPa}>0.6 \mathrm{~mol} \mathrm{~mol}^{-1}$ (a stricter criterion than used for aircraft measurements due to the broad weighting functions in satellite retrievals), we find strong positive correlations ( $r>0.5$, significant with $95 \%$ confidence) between the time series of TES CO and ozone observations for both regions. These correlations, likely driven by contrasts of Asian outflow and clean tropical marine air masses, suggest a combined export of ozone and $\mathrm{CO}$ pollution from the Asian continent. We examine this correlation in more detail below for a well-defined transpacific plume.

\subsection{Transpacific transport event on 5-9 May}

The transpacific event of 5-9 May was observed by both satellites and aircraft. Figure 7 shows daily AIRS and TES observations of $\mathrm{CO}$ for that period along with the corresponding GEOS-Chem simulation. AIRS with its high coverage illustrates the progression of the event and the GEOS-Chem 


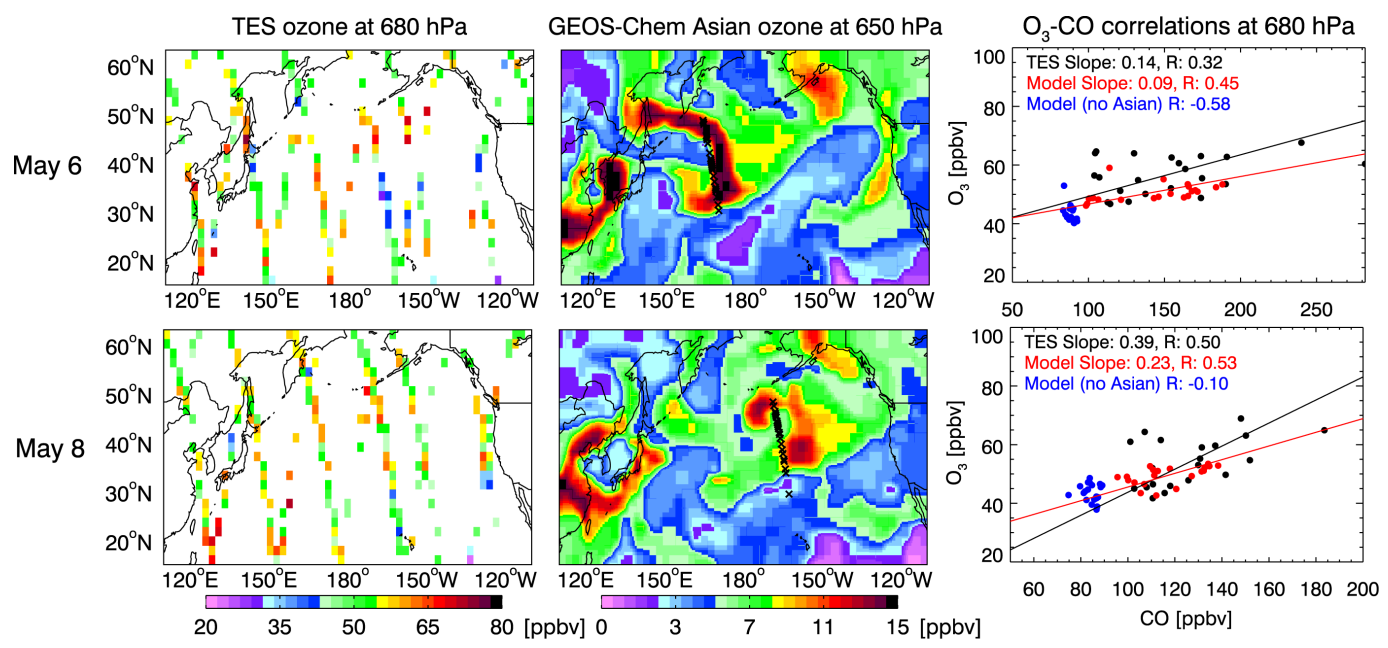

Fig. 8. (left) TES observations of ozone concentrations at $680 \mathrm{hPa}$ on 6 and 8 May. The original TES data have been reprocessed to remove the effect of variable a priori and averaged on the $2^{\circ} \times 2.5^{\circ}$ GEOS-Chem model grid. (center) Simulated Asian ozone enhancement on 6 and 8 May at 12:00 UTC, as determined by difference between the standard GEOS-Chem simulation and a simulation with Asian anthropogenic sources shut off. The black crosses show the locations of the TES observations of the Asian pollution plume used in the $\mathrm{O}_{3}-\mathrm{CO}$ analysis. (right) $\mathrm{O}_{3}-\mathrm{CO}$ relationships at $680 \mathrm{hPa}$ for the plume shown in the central panel. The TES observations (black) are compared to model results from the standard simulation (red) and a sensitivity simulation with Asian emissions shut off (blue) sampled along the TES orbit tracks and with TES averaging kernels applied. Correlation coefficients (r) and slopes of the reduced-major-axis regression lines $\left(\mathrm{dO}_{3} / \mathrm{dCO} \mathrm{mol} \mathrm{mol}^{-1}\right)$ are shown inset.

simulation is highly consistent. The Asian pollution plume is lifted with a southeastward moving front and rapidly transported in westerly winds at $30^{\circ}-50^{\circ} \mathrm{N}$ across the Pacific. It splits into two air streams when crossing the Pacific high pressure system. The northern branch travels to Alaska in a circulation around the Aleutian Low, while the southern branch flows around the Pacific High and impacts the west coast of North America on 9 May.

Also shown in Fig. 7 are the GEOS-Chem model fields sampled along the TES orbit tracks and smoothed with TES averaging kernels. The model reproduces the variability observed by TES $(\mathrm{r}=0.80)$. TES observations are relatively sparse but are qualitatively consistent with AIRS. Figure 8 shows the corresponding TES observations for ozone and the GEOS-Chem simulation of the Asian ozone pollution enhancement (determined by difference between the standard simulation and a sensitivity simulation with Asian anthropogenic sources shut off). Model results display a band of Asian ozone pollution accompanying $\mathrm{CO}$ and moving eastward within $30^{\circ}-50^{\circ} \mathrm{N}$, consistent with the pattern observed by TES.

Figure 8 (right panel) shows the correlations of TES ozone and $\mathrm{CO}$ measurements for the pollution plume at $680 \mathrm{hPa}$. Ozone and CO are positively correlated both in the TES observations and the model. The corresponding observed enhancement ratio $\mathrm{dO}_{3} / \mathrm{dCO}=0.14 \pm 0.05 \mathrm{~mol} \mathrm{~mol}^{-1}$ (standard deviation calculated by the bootstrap method, Venables and Ripley, 1999) on 6 May is smaller than summertime ob- servations of $0.2-0.5 \mathrm{~mol} \mathrm{~mol}^{-1}$ at surface sites in eastern North America (Parrish et al., 1993; Chin et al., 1994), and $0.6 \mathrm{~mol} \mathrm{~mol}^{-1}$ observed in Asian outflow by TES in July (Zhang et al., 2006). The smaller enhancement ratio is likely due to low photochemical activity in the springtime (Pierce et al., 2003). The larger $\mathrm{dO}_{3} / \mathrm{dCO}$ ratio of $0.39 \pm 0.12 \mathrm{~mol} \mathrm{~mol}^{-1}$ observed on 8 May (with $90 \%$ confidence from t-test) is consistent with the typical ratios of $0.2-0.5 \mathrm{~mol} \mathrm{~mol}^{-1}$ in industrial or biomass burning plumes from aircraft measurements over the Northeast Pacific in the spring (Price et al., 2004), and suggests continuous ozone production in the lower troposphere during transport across the Pacific. We see from Fig. 8 that the model reproduces the observed $\mathrm{O}_{3}-\mathrm{CO}$ correlations at least qualitatively and these correlations disappear in a sensitivity simulation without Asian anthropogenic emissions, indicating that they are driven by Asian ozone pollution.

Figure 9 shows the aircraft vertical profiles sampling the pollution plume on the 9 May flight out of Anchorage (flight track shown in Fig. 7). The northern branch sampled at $53^{\circ} \mathrm{N}, 150^{\circ} \mathrm{W}$, and $3.5-7 \mathrm{~km}$ altitude shows $\mathrm{CO}$ up to $182 \mathrm{ppbv}$ and PAN up to $690 \mathrm{pptv}$. Ozone mixing ratios are about $65 \mathrm{ppbv}$, not significantly higher than the local background. The southern branch sampled at $42^{\circ} \mathrm{N}$, $138^{\circ} \mathrm{W}$, and $2.5-5.5 \mathrm{~km}$ altitude shows CO up to $206 \mathrm{ppbv}$ and ozone up to $85 \mathrm{ppbv;}$ PAN mixing ratios (125 pptv) are much lower than in the northern branch. The difference in ozone enhancements reflects the effect of subsidence 

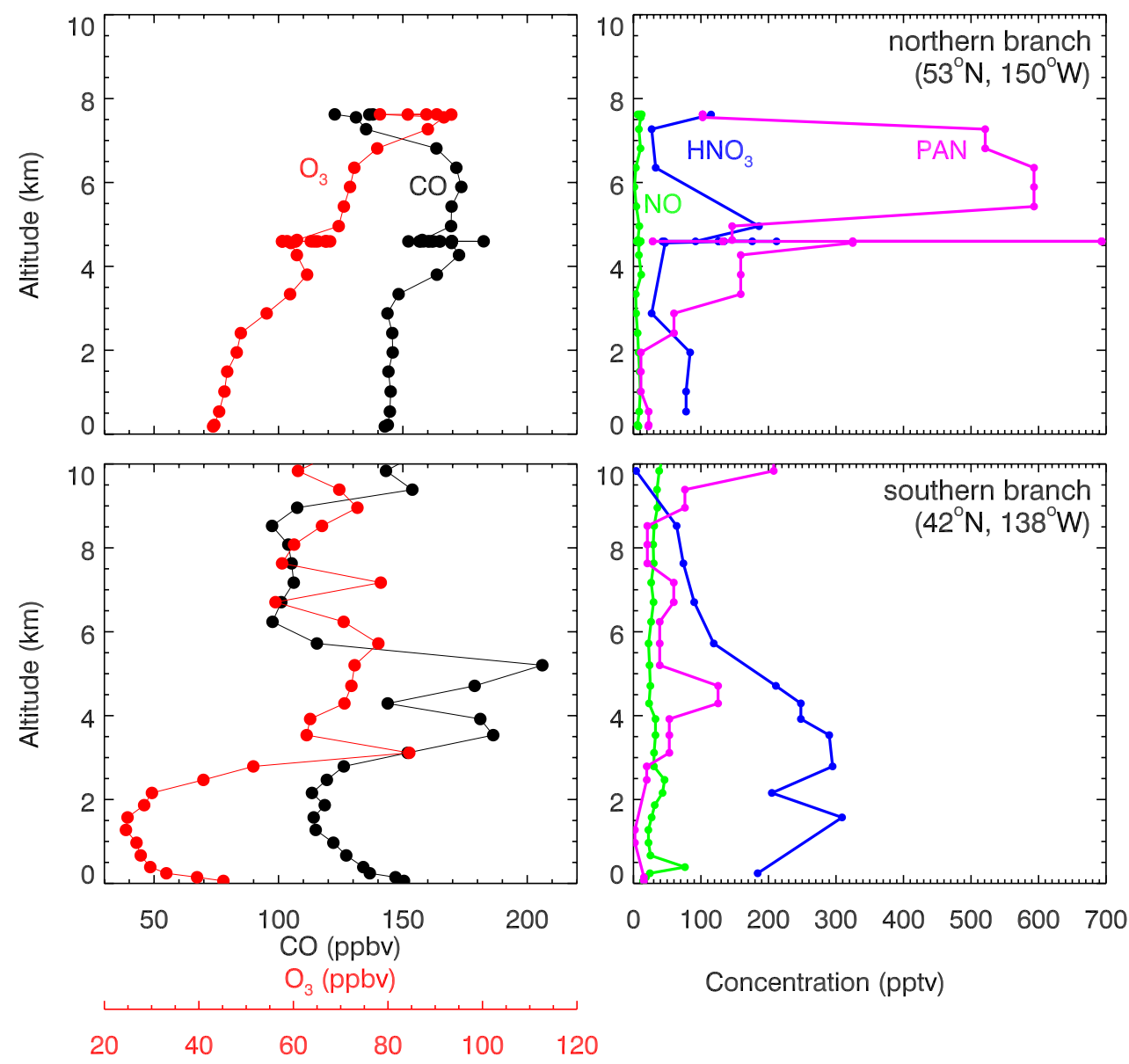

Fig. 9. Observed vertical profiles of concentrations for the northern (top) and southern (bottom) branches of the Asian pollution plume sampled by the INTEX-B DC-8 flight on 9 May. (left) CO (solid black) and ozone (solid red). (right) $\mathrm{NO}_{\mathrm{y}}$ components: PAN (solid purple), $\mathrm{HNO}_{3}$ (solid blue), and NO (solid green).

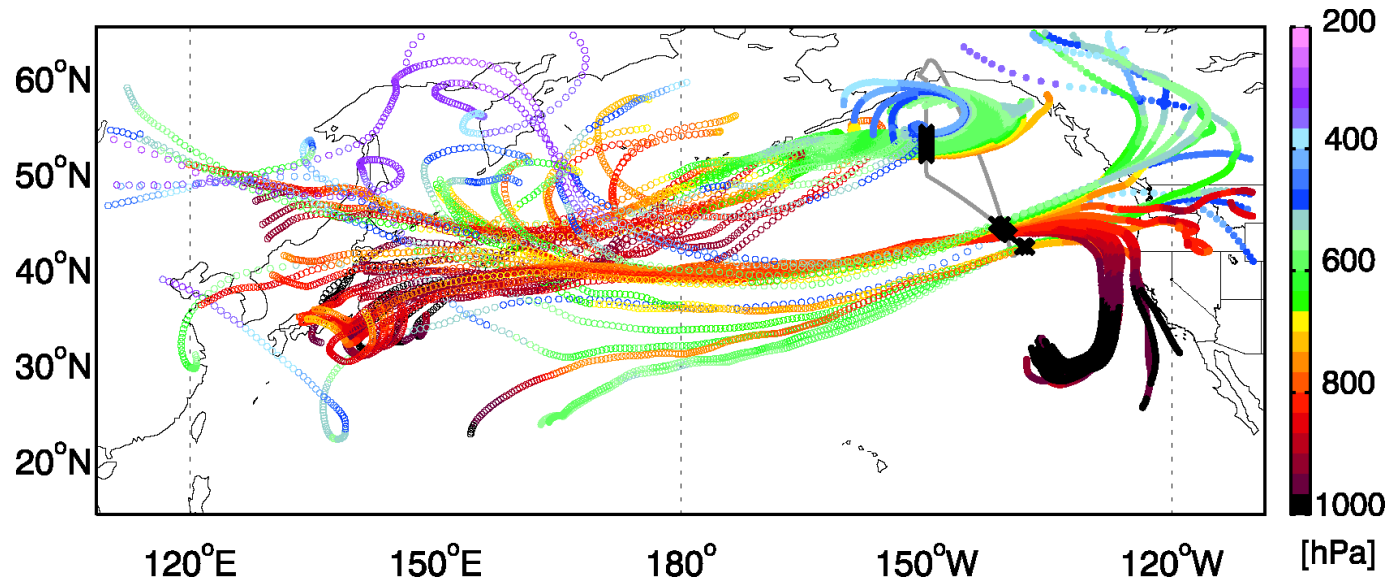

Fig. 10. Kinematic 7-day backward (open circles) and 3-day forward (solid circles) trajectories for the enhanced CO layers of Asian pollution $(\mathrm{CO}>125 \mathrm{ppbv}$ and 2-7 km) observed in the INTEX-B DC-8 flight on May 9 as shown in Fig. 9. The flight track is shown in gray and the black crosses show the locations of enhanced CO layers, corresponding to the northern and southern branches of Fig. 9. The trajectories were constructed using reanalysis data from the National Centers for Environmental Prediction (Fuelberg et al., 2007). 


\section{Enhanced ozone production rate from Asian emissions at $800 \mathrm{hPa}$}

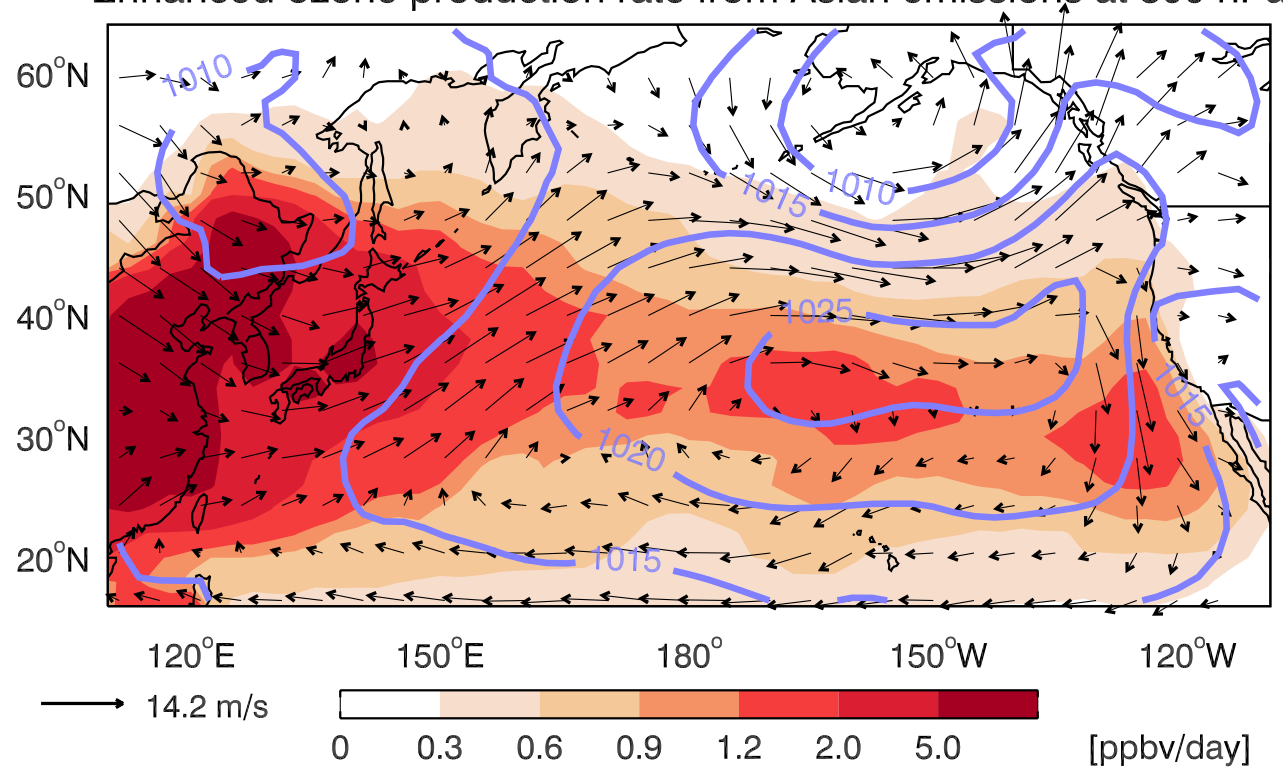

Fig. 11. Mean gross ozone (odd oxygen) production rate at $800 \mathrm{hPa}$ from anthropogenic Asian emissions during the INTEX-B period (17 April-15 May 2006). The Asian enhancement of ozone production is determined by the difference of gross ozone production rates between the standard simulation and a sensitivity simulation with Asian anthropogenic emissions shut off. The contours and vectors represent the mean GEOS-4 sea level pressures and $800 \mathrm{hPa}$ wind fields for the period.
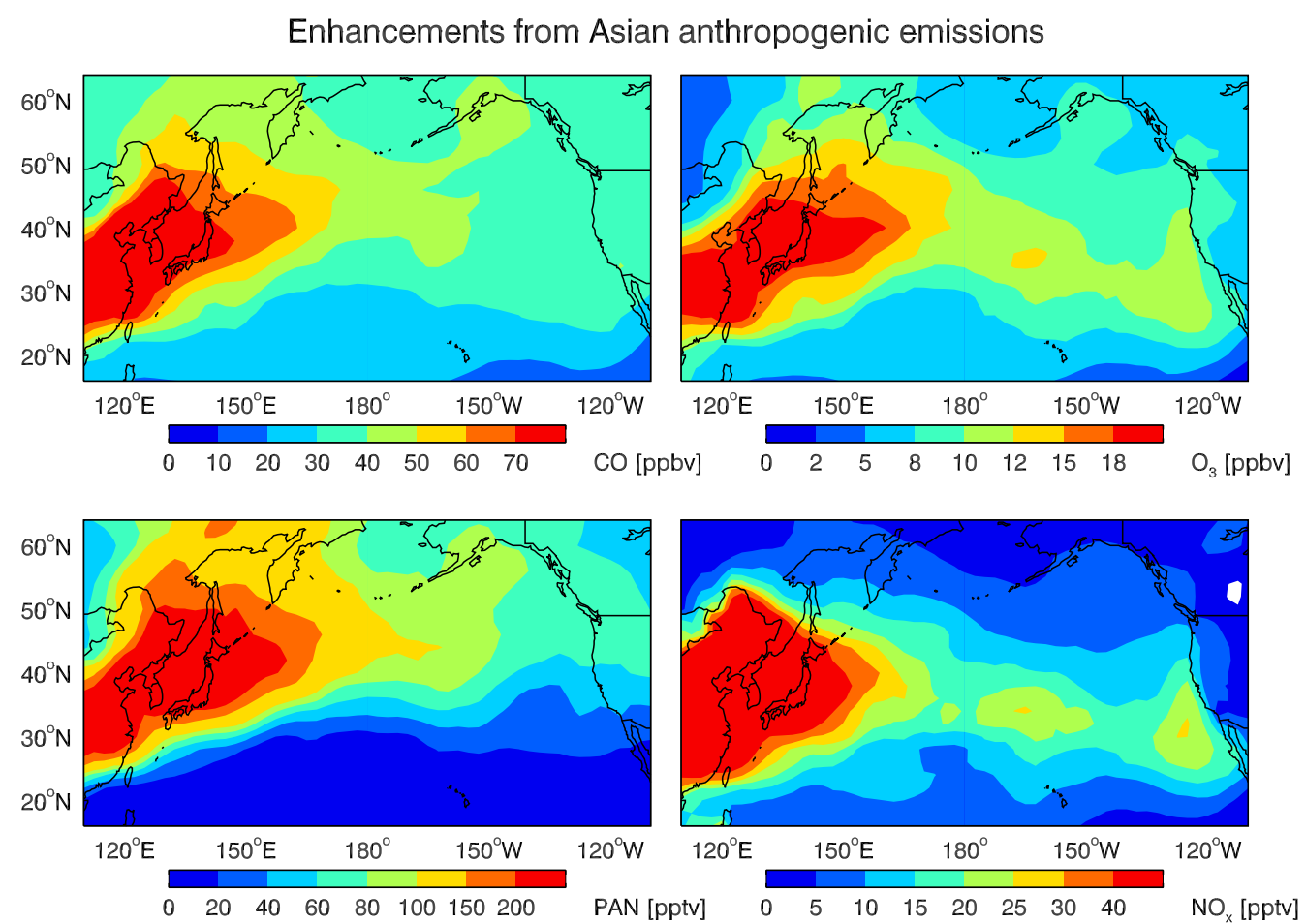

Fig. 12. Mean GEOS-Chem simulated Asian pollution enhancements of ozone, CO, $\mathrm{NO}_{\mathrm{x}}$, and PAN at $800 \mathrm{hPa}$ for the INTEX-B period (17 April-15 May 2006). The Asian pollution enhancements are determined by difference between the standard simulation and a sensitivity simulation with Asian anthropogenic emissions shut off. 

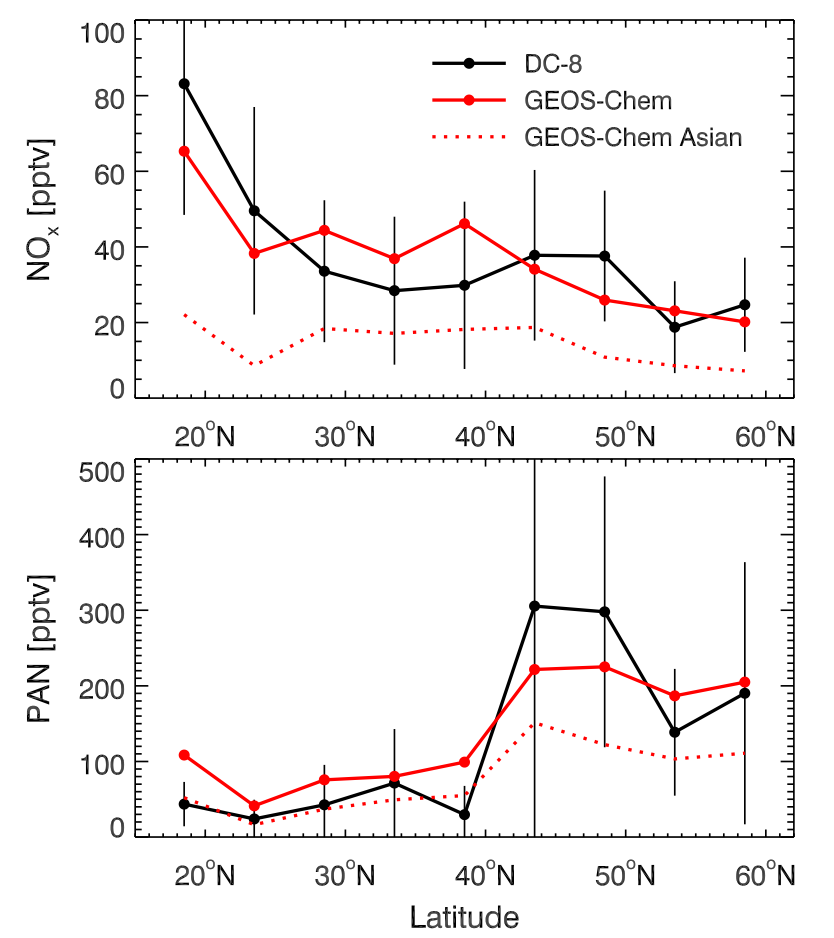

Fig. 13. Mean latitudinal distributions of $\mathrm{NO}_{\mathrm{x}}$ and PAN concentrations over the Northeast Pacific at $1.5-5 \mathrm{~km}$ altitude during the INTEX-B period. Model results (red solid) are compared to the INTEX-B observations (black solid). Red dashed lines show the model Asian enhancements. Vertical bars are standard deviations of the observations.

driving PAN decomposition to $\mathrm{NO}_{\mathrm{x}}$ and hence ozone production (Kotchenruther et al., 2001; Heald et al., 2003; Hess and Vukicevic, 2003; Hudman et al., 2004; Nowak et al., 2004).

The ozone production in the southern branch is relevant for direct impact on the United States. Figure 10 shows kinematic backward and forward trajectories based on reanalysis data from National Centers for Environmental Prediction (Fuelberg et al., 2007) for the enhanced CO layers of Asian pollution ( $\mathrm{CO}>125 \mathrm{ppbv}$ and $2-7 \mathrm{~km}$ ) shown in Fig. 9. The 9 May flight measured distinct northern and southern branches of the plumes, but the backward trajectories in Fig. 10 demonstrate their common origin. The 3-day forward trajectories from the aircraft tracks show the different fates of the two pollution branches. The northern branch remains at high altitude over the Gulf of Alaska, while the southern branch subsides to impact the United States. However, a large part of that southern branch cycles around the Pacific High and avoids contact with North America.
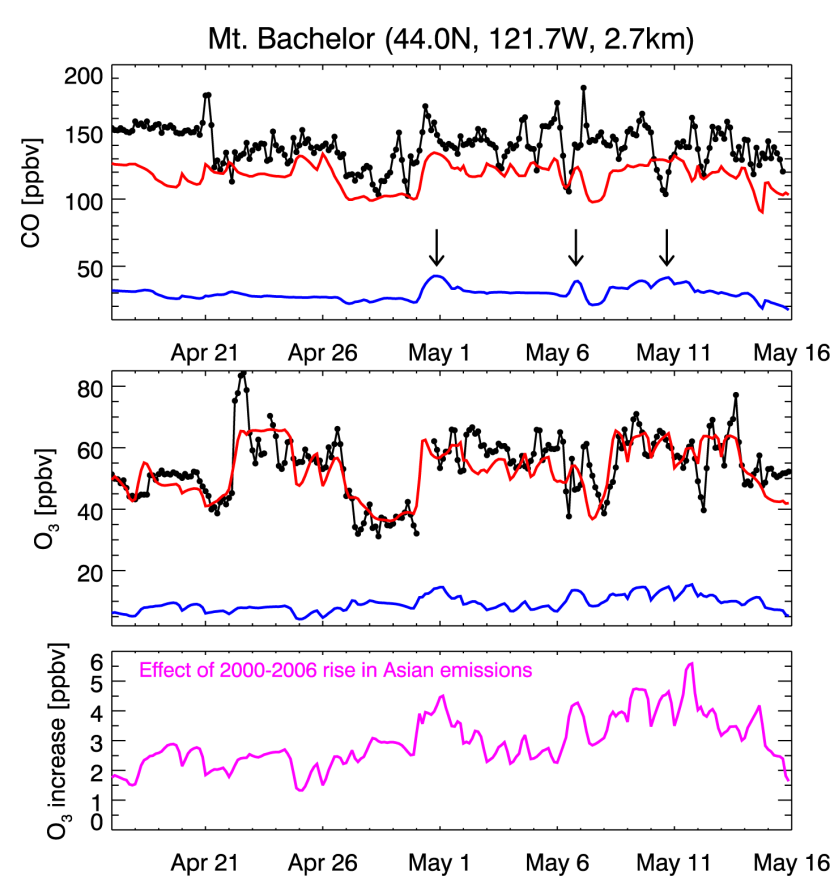

Fig. 14. Time series of 3-hourly averaged CO (top) and ozone (center) concentrations at MBO during the INTEX-B period. Model results (red) are compared to observations (black). The blue lines show the Asian anthropogenic enhancements in the model as determined by the difference between the standard simulation and a sensitivity simulation with Asian anthropogenic emissions shut off. Black arrows show Asian CO pollution maxima as indicated by the model. The bottom panel shows the simulated increase of ozone concentrations at MBO due to the rise of Asian anthropogenic emissions from 2000 to 2006 .

\section{Mean transpacific transport of Asian ozone and its precursors}

We now generalize from the case study of 6-9 May to the mean transpacific Asian pollution influence during the INTEX-B period of 17 April-15 May, 2006. Figure 11 shows the mean enhancements of gross ozone production rates at $800 \mathrm{hPa}$ due to Asian anthropogenic emissions, as determined by difference between the standard simulation and the sensitivity simulation with Asian anthropogenic emissions shut off. GEOS-Chem ozone production rates in the standard simulation are consistent with those from box models constrained by aircraft measurements over the Northwest Pacific (Auvray et al., 2007). Transpacific transport of ozone pollution mostly takes place in the free troposphere (Price et al., 2004), and we show $800 \mathrm{hPa}$ in Fig. 11 as most relevant for North American air quality. We see fast production of Asian ozone pollution ( $>5 \mathrm{ppbv} \mathrm{d}^{-1}$ ) over the Asian continent where $\mathrm{NO}_{\mathrm{x}}$ concentrations are high, but also sustained production ( $>1 \mathrm{ppbv} \mathrm{d}^{-1}$ ) across the Pacific at $25^{\circ} \mathrm{N}-40^{\circ} \mathrm{N}$ and a secondary maximum off the coast of California. Hudman et al. (2004) previously found that the ozone production 

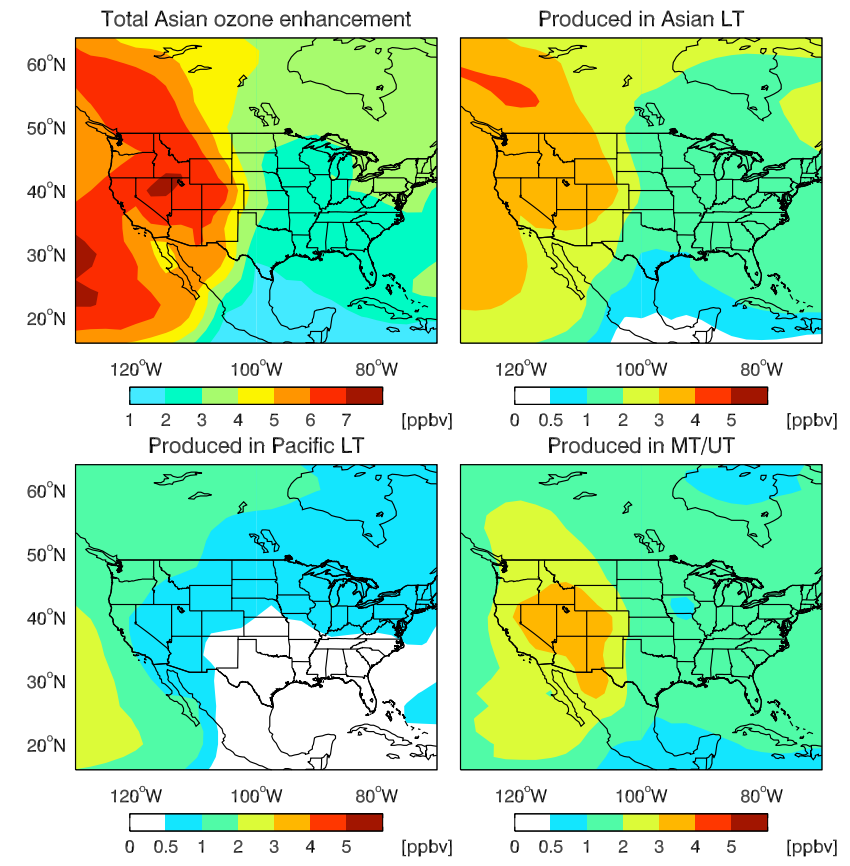

Fig. 15. Mean simulated US surface ozone enhancements from Asian anthropogenic emissions during the INTEX-B time period (17 April-15 May 2006). Total Asian ozone enhancements (top left) are separated into linear contributions from ozone produced in the Asian and Pacific lower troposphere (surface - $700 \mathrm{hPa}$ ), and in the middle/upper troposphere $(700 \mathrm{hPa}$ - tropopause). Note that the top left panel has a different scale than the others.

efficiency is particularly high over the subsiding East Pacific because of the strong radiation and low humidity. This combined with the release of $\mathrm{NO}_{\mathrm{x}}$ from PAN decomposition promotes relatively rapid ozone production $\left(>1.5 \mathrm{ppbv} \mathrm{d}^{-1}\right)$.

Mean $800 \mathrm{hPa}$ winds and sea level pressures for the INTEX-B period are also shown in Fig. 11. The Pacific High and Aleutian Low are prominent features and drive the westerly transport across the central and eastern Pacific (Liang et al., 2005). We see from Fig. 11 that splitting of Asian plumes over the Northeast Pacific is an expected feature of the mean circulation: the northern branch circulates around the Aleutian Low, while the southern branch circulates around the Pacific High and affects the western United States. As shown in Fig. 11, the high ozone production rate is limited to the southern branch. Most of the air in that southern branch actually skirts the US, as previously discussed in the May 5-9 case. It is instead entrained in the easterly tropical circulation to become the tropical "river of pollution" flowing back to the western equatorial Pacific in the marine boundary layer, as observed in the PEM-Tropics B aircraft campaign (Staudt et al., 2001; Martin et al., 2003).
Figure 12 shows the mean simulated Asian pollution enhancements of $\mathrm{CO}, \mathrm{PAN}$, ozone, and $\mathrm{NO}_{\mathrm{x}}$ at $800 \mathrm{hPa}$ for the INTEX-B period. They show the same pattern of Asian outflow but then become latitudinally separated during transport across the Pacific. $\mathrm{CO}$ and PAN have little production over the Pacific; their transport is mainly north of $35^{\circ} \mathrm{N}$. By contrast, Asian ozone and $\mathrm{NO}_{\mathrm{x}}$ are more enhanced at $25^{\circ} \mathrm{N}-$ $40^{\circ} \mathrm{N}$, corresponding to the southern branch of transpacific transport in Fig. 11 which provides a sustained source. The secondary maxima of Asian $\mathrm{NO}_{\mathrm{x}}$ and ozone over the subtropical Pacific match the secondary maxima of Asian ozone production in Fig. 11.

The INTEX-B aircraft observations provide evidence for this latitudinal separation between Asian enrichments of $\mathrm{NO}_{\mathrm{x}}$ and PAN. Figure 13 shows the mean observed and simulated latitudinal gradients of $\mathrm{NO}_{\mathrm{x}}$ and PAN concentrations over the Northeast Pacific at $1.5-5 \mathrm{~km}$ altitude. $\mathrm{NO}_{\mathrm{x}}$ concentrations decrease with increasing latitude while PAN increases with increasing latitude, with a step function at $40^{\circ} \mathrm{N}$. The patterns are similar in the model and in the observations, confirming the mechanism of ozone production driven by PAN decomposition over the subtropical Pacific.

\section{Impact of Asian pollution on North American surface ozone}

\subsection{Measurements at Mt. Bachelor Observatory}

The Mt. Bachelor Observatory, a mountain site in central Oregon, is particularly sensitive to Asian influences due to its exposure to the free troposphere (Jaffe et al., 2005; WeissPenzias et al., 2006). We use measurements at MBO to test model estimates of Asian influence in North American background air. Figure 14 shows the 3-hourly observed and modeled time series of $\mathrm{CO}$ and ozone at MBO during the INTEX$B$ period. The model is unbiased for ozone and biased low by $20 \mathrm{ppbv}$ for $\mathrm{CO}$, as discussed previously in the context of the aircraft data. The synoptic-scale variability is well captured, particularly for ozone. The model predicts larger Asian pollution ozone enhancements in May than April due to increasing photochemical activity. May is climatologically the month of peak Asian influence on US ozone (Jacob et al., 1999). The day-to-day temporal variability of Asian ozone pollution simulated by the model is small, consistent with the previous analyses of Fiore et al. (2002) and Goldstein et al. (2004). Asian ozone pollution in the model mostly appears as a background enhancement rather than as discrete plumes. PAN concentrations measured at MBO during INTEX-B have a median of 270 pptv (Wolfe et al., 2007), compared to $190 \mathrm{pptv}$ in GEOS-Chem, with fair agreement in temporal patterns between model and observations $(r=0.56)$.

Asian plumes with enhanced $\mathrm{CO}$ and ozone concentrations have been previously observed at MBO (Jaffe et al., 2005; Weiss-Penzias et al., 2007). The INTEX-B period is unusual 
in that no strong plumes of $\mathrm{CO}$ were detected at MBO (Reidmiller et al., 2008). Arrows in Fig. 14 show Asian CO pollution maxima as indicated by the model and discussed further by Wolfe et al. (2007). Detecting these Asian pollution events in the $\mathrm{CO}$ observations is a challenge because of other, larger factors of variability. The observed $\mathrm{CO}$ enhancement on 1 May could be of Asian origin. The ozone observations show a coincident sharp increase but the model implies that only a small part of that increase is due to Asian emissions.

The mean observed ozone concentration at $\mathrm{MBO}$ during INTEX-B is $54 \pm 10 \mathrm{ppbv}$ (mean \pm standard deviation), compared with $53 \pm 9 \mathrm{ppbv}$ in the model. It is lower than the mean ozone observed at Trinidad Head and Richland at $2.7 \mathrm{~km}$ during INTEX-B ( $60 \mathrm{ppbv}$ and $62 \mathrm{ppbv}$, respectively as shown in Fig. 5), because stratospheric influence at MBO is weaker (Weiss-Penzias et al., 2006). Asian anthropogenic emissions in the model increase ozone concentrations at $\mathrm{MBO}$ by $9.2 \pm 2.5 \mathrm{ppbv}$ for the INTEX-B time period. Asian pollution is thus an important component of the model ozone background at MBO; without this contribution the model would greatly underestimate the measurements. In a previous study with the GEOS-Chem model, Hudman et al. (2004) found a mean Asian pollution enhancement of $7 \mathrm{ppbv}$ ozone at a California mountain site in May 2002. The difference can be explained by rising Asian emissions. As shown in the bottom panel of Fig. 14, rising Asian emissions from 2000 to 2006 have increased ozone at MBO by 3 ppbv on average in AprilMay and up to $5 \mathrm{ppbv}$ in events, although a small part of that increase could reflect the underestimate of emissions for Japan and Korea in the baseline S2000 inventory for 2000.

\subsection{Impact on surface ozone air quality}

Figure 15 (top left panel) shows the mean simulated surface ozone enhancement from Asian anthropogenic emissions over North America for the INTEX-B period. Asian ozone enhancements are 5-7 ppbv in the west and 2-5 ppbv in the east. The highest values are in the mountainous west.

To interpret these results we conducted two tagged $\mathrm{O}_{\mathrm{x}}$ simulations, one using archived 3-D fields of daily production rates and loss frequencies from the standard simulation, and the other using those from the sensitivity simulation with Asian anthropogenic emissions shut off. The difference of the two simulations diagnoses the contributions from different production regions as sources of transpacific Asian ozone pollution. We thus distinguish in Fig. 15 between production in the Asian lower troposphere (up to $700 \mathrm{hPa}$ ), production in the Pacific lower troposphere (up to $700 \mathrm{hPa}$ ), and production in the middle and upper troposphere (above $700 \mathrm{hPa}$ ). Summation of these three tagged tracers gives the total Asian pollution ozone enhancement in the top left panel.

As shown in Fig. 15, most of the Asian ozone enhancement in western Canada is from transport of ozone produced in the Asian lower troposphere. The western United States and northern Mexico are more influenced by the south- ern branch of transpacific transport, where continuous ozone production from exported Asian $\mathrm{NO}_{\mathrm{x}}$ and PAN is comparable in magnitude to direct transport from the Asian boundary layer. Ozone production in the middle and upper troposphere is more important for US influence than in the subsiding air masses below $700 \mathrm{hPa}$ (Pacific lower troposphere), as ozone produced in the latter region tends to remain over the subtropical Pacific rather than affect North America (Fig. 10 and 15).

Previous studies reported that pollution transported from Asia may contribute $3-5$ ppbv to the ozone background over the western United States in the spring (Berntsen et al., 1999; Yienger et al., 2000). We find in the model that the 20002006 rise of Asian anthropogenic emissions increased surface ozone by 1-2 ppbv in the western United States (the larger impact of $3 \mathrm{ppbv}$ at MBO is on account of its elevation). We conducted further sensitivity simulations to separate the contributions from the $100 \%$ rise in Asian $\mathrm{NO}_{\mathrm{x}}$ emissions and the $45 \%$ rise in Asian NMVOC emissions, as the latter would affect PAN formation, and find that the ozone enhancement is most sensitive to $\mathrm{NO}_{\mathrm{x}}$ emissions. The rise in Asian NMVOC emissions alone increases ozone by at most 0.4 ppbv anywhere in North America.

\section{Conclusions}

We used an ensemble of aircraft, satellite, sonde, and surface observations during the INTEX-B two-aircraft campaign over the Northeast Pacific (April-May 2006) to better understand and quantify the transpacific transport of Asian pollution and its effect on North American ozone air quality. We interpreted this ensemble of observations with a global 3-D model of tropospheric chemistry (GEOS-Chem). We addressed the impact of the recent rise in Asian emissions (2000-2006) on surface ozone air quality in North America.

Tropospheric $\mathrm{NO}_{2}$ column observations from the OMI satellite instrument provide top-down constraints on anthropogenic $\mathrm{NO}_{\mathrm{x}}$ emissions in eastern Asia (including China, Japan, and Korea) in April-May 2006. We find a factor of 2 increase compared with the anthropogenic $\mathrm{NO}_{\mathrm{x}}$ emission inventory from Streets et al. (2003) for the year 2000. This factor of 2 increase reflects a combination of 2000-2006 actual growth of Asian $\mathrm{NO}_{\mathrm{x}}$ emissions (China) and an underestimate in the prior inventory (Korea, Japan). China accounted for over $80 \%$ of eastern Asian anthropogenic $\mathrm{NO}_{\mathrm{x}}$ emissions as of 2006 .

The model provides a good simulation of the ozone, $\mathrm{NO}_{\mathrm{x}}$, and PAN mean vertical profiles observed from the two INTEX-B aircraft. The simulation is only weakly sensitive to the 2000-2006 rise of Asian emissions in terms of comparison to observations; ozone increases by $3 \mathrm{ppbv}$ on average. Simulated ozone over the west coast of North America is $5 \mathrm{ppb}$ lower than observed from aircraft and ozonesondes during INTEX-B, which we attribute to 
preferential stratospheric inflow over this region not resolved by the model. The model is $15 \%$ too low for CO compared to the aircraft observations, which we attribute tentatively to excessive $\mathrm{OH}$ (model values for $\mathrm{OH}$ are $27 \%$ higher than observed in INTEX-B).

Satellite observations of CO columns from AIRS and TES indicate at least two major events of transpacific Asian pollution during the INTEX-B time period. Tropospheric ozone observations from TES do not show a simple correlation with $\mathrm{CO}$, reflecting at least in part the complicating effect of stratospheric influence. Filtering out this stratospheric influence reveals strong positive correlations between TES CO and ozone over the North Pacific. These correlations, likely driven by contrasts of Asian outflow and clean tropical marine air masses, indicate collocated export of ozone and $\mathrm{CO}$ pollution from the Asian continent.

We examined in detail a major transpacific Asian pollution plume sampled by the INTEX-B aircraft on 9 May. Measurements from AIRS and TES tracked the transpacific progression of this event. TES observed positive $\mathrm{O}_{3}-\mathrm{CO}$ correlations in the pollution plume, offering some evidence for net ozone production during transport across the Pacific. The plume split into northern and southern branches over the Northeast Pacific. Elevated ozone was observed by aircraft in the subsiding southern branch and was consistent with production from PAN decomposition.

Generalization to the mean transpacific Asian pollution influence during the INTEX-B period showed that this splitting of pollution plumes into two branches over the Northeast Pacific is an expected climatological feature driven by the circulations around the Pacific High and the Aleutian Low. The northern branch circulates around the Aleutian Low and remains at high altitude. The southern branch subsides around the Pacific High to affect the United States and northern Mexico, although most of that air skirts North America and is entrained in the easterly tropical circulation toward the western equatorial Pacific. Model results show high ozone production rates from Asian pollution in the southern branch, including a secondary maximum off the coast of California driven by subsidence. Concentrations of $\mathrm{NO}_{\mathrm{x}}$ and PAN measured from the aircraft show opposite latitudinal gradients in the lower troposphere, consistent with the model, and confirming the mechanism of PAN decomposition to $\mathrm{NO}_{\mathrm{x}}$ as a driver for transpacific ozone production.

We tested the model simulation of Asian pollution influences over North America with measurements at Mt. Bachelor Observatory (MBO) in central Oregon ( $2.7 \mathrm{~km}$ altitude). The model reproduces the ozone observations at MBO with no significant bias. Asian ozone pollution increases ozone concentrations in the model at MBO by $9.2 \pm 2.5 \mathrm{ppbv}$ for the INTEX-B time period, representing an important contribution to total ozone in the model ( $53 \pm 9$ ppbv) and its ability to fit observations $(54 \pm 10 \mathrm{ppbv})$. The temporal variability of Asian ozone in the model is still small and undetectable in the observations. The 2000-2006 rise in Asian anthro- pogenic emissions increased model ozone at MBO by 3 ppbv on average and up to 5 ppbv in events.

We find that Asian anthropogenic emissions increased surface ozone concentrations by 5-7 ppbv in western North America during the INTEX-B period. The 2000-2006 rise in Asian anthropogenic emissions, including in particular the doubling of $\mathrm{NO}_{\mathrm{x}}$ emissions, increased that influence by 1-2 ppbv. Most of the Asian ozone pollution in western Canada originates from production in the lower troposphere over the Asian continent. The western United States and northern Mexico are more impacted by the southern branch of transpacific transport, which has sustained ozone production during transpacific transport driven by decomposition of PAN. About half of Asian anthropogenic ozone affecting the United States is produced in the Asian lower troposphere while the other half is produced during transpacific transport.

Acknowledgements. This work was funded by the NASA Global Tropospheric Chemistry Program and by NASA Headquarters under the Earth and Space Science Fellowship Program Grant NNX07AN65H to Lin Zhang.

Edited by: S. Madronich

\section{References}

Aumann, H. H., Chahine, M. T., Gautier, C., Goldberg, M. D., Kalnay, E., McMillin, L. M., Revercomb, H., Rosenkranz, P. W., Smith, W. L., Staelin, D. H., Strow, L. L., and Susskind, J.: AIRS/AMSU/HSB on the Aqua mission: Design, science objectives, data products and processing systems, IEEE T. Geosci. Remote, 41, 253-264, 2003.

Auvray, M., Bey, I., Llull, E., Schultz, M. G., and Rast, S.: A model investigation of tropospheric ozone chemical tendencies in long-range transported pollution plumes, J. Geophys. Res., 112, D05304, doi:10.1029/2006JD007137, 2007.

Barletta, B., Meinardi, S., Atlas, E., Blake, N. J., Baker, A. K., Beyersdorf, A. J., McKeachie, R., Midyett, J. R., Novak, B. J., Yang, M., and Blake, D. R.: Nonmethane Hydrocarbon (NMHC) Characterization of Asian Outflow During the INTEX-B Campaign: a Case Study from May 1, Eos Trans. AGU, 88(52), Fall Meet. Suppl., Abstract A33A-0822, 2007.

Beer, R., Glavich, T. A., and Rider, D. M.: Tropospheric Emission Spectrometer for the Earth Observing System's Aura satellite, Appl. Opt., 40, 2356-2367, 2001.

Berntsen, T. K., Karlsdottir, S., and Jaffe, D. A.: Influence of Asian emissions on the composition of air reaching the Northwestern United States, Geophys. Res. Lett., 26, 2171-2174, 1999.

Bertschi, I. B., Jaffe, D. A., Jaeglé, L., Price, H. U., and Dennison, J. B.: PHOBEA/ITCT 2002 airborne observations of trans-Pacific transport of ozone, $\mathrm{CO}$, VOCs and aerosols to the northeast Pacific: Impacts of Asian anthropogenic and Siberian Boreal fire emissions, J. Geophys. Res., 109, D23S12, doi:10.1029/2003JD004328, 2004.

Bey, I., Jacob, D. J., Yantosca, R. M., Logan, J. A., Field, B. D., Fiore, A. M., Li, Q., Liu, H., Mickley, L. J., and Schultz, M. G.: Global modeling of tropospheric chemistry with assimilated me- 
teorology: Model description and evaluation, J. Geophys. Res., 106, 23 073-23 089, 2001.

Boersma, K. F., Eskes, H. J., Veefkind, J. P., Brinksma, E. J., van der A, R. J., Sneep, M., van den Oord, G. H. J., Levelt, P. F., Stammes, P., Gleason, J. F., and Bucsela, E. J.: Near-real time retrieval of tropospheric $\mathrm{NO}_{2}$ from OMI, Atmos. Chem. Phys., 7, 2103-2118, 2007,

http://www.atmos-chem-phys.net/7/2103/2007/.

Boersma, K. F., Jacob, D. J., Bucsela, E. J., Perring, A. E., Dirksen, R., van der A, R. J., Yantosca, R. M., Park, R. J., Wenig, M. O., Bertram, T. H., and Cohen, R. C.: Validation of OMI tropospheric $\mathrm{NO}_{2}$ observations during INTEX$\mathrm{B}$ and application to constrain $\mathrm{NO}_{\mathrm{x}}$ emissions over the eastern United States and Mexico, Atmos. Environ., 42(19), doi:10.1016/j.atmosenv.2008.02.004, 4480-4497, 2008.

Bowman, K. W., Rodgers, C. D., Kulawik, S. S., Worden, J., Sarkissian, E., Osterman, G., Steck, T., Lou, M., Eldering, A., Shephard, M., Worden, H., Lampel, M., Clough, S., Brown, P., Rinsland, C., Gunson, M., and Beer, R.: Tropospheric emission spectrometer: Retrieval method and error analysis, IEEE T. Geosci. Remote, 44(5), 1297-1307, 2006.

Brock, C. A., Hudson, P. K., Lovejoy, E. R., and et al.: Particle characteristics following cloud-modified transport from Asia to North America, J. Geophys. Res., 109, D23S26, doi:10.1029/2003JD004198, 2004.

Chen, G., Kleb, M. M., Brune, W. H., and Flocke, F. M.: An Overview of INTEX-B/MILAGRO/IMPEX Instrument and Measurement Intercomparison, Eos Trans. AGU, 88(52), Fall Meet. Suppl., Abstract A33A-0817, 2007.

Chin, M., Jacob, D. J., Munger, J. W., Parrish, D. D., and Doddridge, B. G.: Relationship of ozone and carbon monoxide over North America, J. Geophys. Res., 99, 14 565-14 573, 1994.

Cooper, O. R., Forster, C., Parrish, D., Trainer, M., Dunlea, E., Ryerson, T., Hübler, G., Fehsenfeld, F., Nicks, D., Holloway, J., de Gouw, J., Warneke, C., Roberts, J. M., Flocke, F., and Moody, J.: A case study of transpacific warm conveyor belt transport: Influence of merging airstreams on trace gas import to North America, J. Geophys. Res., 109, D23S08, doi:10.1029/2003JD003624, 2004.

Dickerson, R. R., Li, C., Li, Z., Marufu, L. T., Stehr, J. W., McClure, B., Krotkov, N., Chen, H., Wang, P., Xia, X., Ban, X., Gong, F., Yuan, J., and Yang, J.: Aircraft observations of dust and pollutants over northeast China: Insight into the meteorological mechanisms of transport, J. Geophys. Res., 112, D24S90, doi:10.1029/2007JD008999, 2007.

Duncan, B. N., Martin, R. V., Staudt, A. C., Yevich, R., and Logan, J. A.: Interannual and seasonal variability of biomass burning emissions constrained by satellite observations, J. Geophys. Res., 108(D2), 4100, doi:10.1029/2002JD002378, 2003.

Fiore, A. M., Jacob, D. J., Bey, I., Yantosca, R. M., Field, B. D., Fusco, A. C., and Wilkinson, J. G.: Background ozone over the United States in summer: Origin, trend, and contribution to pollution episodes, J. Geophys. Res., 107(D15), 4275, doi:10.1029/2001JD000982, 2002.

Fiore, A., Jacob, D. J., Liu, H., Yantosca, R. M., Fairlie, T. D., and Li, Q.: Variability in surface ozone background over the United States: Implications for air quality policy, J. Geophys. Res., 108(D24), 4787, doi:10.1029/2003JD003855, 2003.

Forster, C., Cooper, O., Stohl, A., Eckhardt, S., James, P., Dun- lea, E., Nicks Jr., D. K., Holloway, J. S., Hübler, G., Parrish, D. D., Ryerson, T. B., and Trainer, M.: Lagrangian transport model forecasts and a transport climatology for the Intercontinental Transport and Chemical Transformation 2002 (ITCT 2K2) measurement campaign, J. Geophys. Res., 109, D07S92, doi:10.1029/2003JD003589, 2004.

Fuelberg, H. E., Porter, M. J., Kiley, C. M., Halland, J. J., and Morse, D.: Meteorological conditions and anomalies during the Intercontinental Chemical Transport Experiment-North America, J. Geophys. Res., 112, D12S06, doi:10.1029/2006JD007734, 2007.

Goldstein, A. H., Millet, D. B., McKay, M., Jaeglé, L., Horowitz, L., Cooper, O., Hudman, R., Jacob, D. J., Oltmans, S., and Clarke, A.: Impact of Asian emissions on observations at Trinidad Head, California, during ITCT 2K2, J. Geophys. Res., 109, D23S17, doi:10.1029/2003JD004406, 2004.

Heald, C. L., Jacob, D. J., Fiore, A. M., Emmons, L. K., Gille, J. C., Deeter, M. N., Warner, J., Edwards, D. P., Crawford, J. H., Hamlin, A. J., Sachse, G. W., Browell, E. V., Avery, M. A., Vay, S. A., Westberg, D. J., Blake, D. R., Singh, H. B., Sandholm, S. T., Talbot, R. W., and Fuelberg, H. E.: Asian outflow and transpacific transport of carbon monoxide and ozone pollution: An integrated satellite, aircraft and model perspective, J. Geophys. Res., 108(D24), 4804, doi:10.1029/2003JD003507, 2003.

Heald, C. L., Jacob, D. J., Park, R. J., Alexander, B., Fairlie, D., Yantosca, R. M., and Chu, A.: Transpacific transport of Asian anthropogenic aerosols and its impact on surface air quality in the United States, J. Geophys. Res., 111, D14310, doi:10.1029/2005JD006847, 2006.

Hess, P. G. and Vukicevic, T.: Intercontinental transport, chemical transformations, and baroclinic systems, J. Geophys. Res., 108(D12), 4354, doi:10.1029/2002JD002798, 2003.

Hudman, R. C., Jacob, D. J., Cooper, O. R., Evans, M. J., Heald, C. L., Park, R. J., Fehsenfeld, F., Flocke, F., Holloway, J., Hübler, G., Kita, K., Koike, M., Kondo, Y., Neuman, A., Nowak, J., Oltmans, S., Parrish, D., Roberts, J. M., and Ryerson, T.: Ozone production in transpacific Asian pollution plumes and implications for ozone air quality in California, J. Geophys. Res., 109, D23S10, doi:10.1029/2004JD004974, 2004.

Hudman, R. C., Jacob, D. J., Turquety, S., Leibensperger, E. M., Murray, L. T., Wu, S., Gilliland, A. B., Avery, M., Bertram, T. H., Brune, W., Cohen, R. C., Dibb, J. E., Flocke, F. M., Fried, A., Holloway, J., Neuman, J. A., Orville, R., Perring, A., Ren, X., Sachse, G. W., Singh, H. B., Swanson, A., and Wooldridge, P. J.: Surface and lightning sources of nitrogen oxides over the United States: Magnitudes, chemical evolution, and outflow, J. Geophys. Res., 112, D12S05, doi:10.1029/2006JD007912, 2007.

Huntrieser, H., Schlager, H., Höller, H., Schumann, U., Betz, H. D., Boccippio, D., Brunner, D., Forster, C., and Stohl, A.: Lightning produced $\mathrm{NO}_{\mathrm{x}}$ in tropical, subtropical and midlatitude thunderstorms: New insights from airborne and lightning observations, Geophys. Res. Abstr., 8, 03286, SRef-ID:16077962/gra/EGU06-A-03286, 2006.

Jaeglé, L., Jaffe, D. A., Price, H. U., Weiss, P., Palmer, P. I., Evans, M. J., Jacob, D. J., and Bey, I.: Sources and budgets for CO and $\mathrm{O}_{3}$ in the Northeastern Pacific during the spring of 2001: Results from the PHOBEA-II Experiment, J. Geophys. Res., 108(D20), 8802, doi:10.1029/2002JD003121, 2003.

Jaeglé, L., Steinberger, L., Martin, R. V., and Chance, K.: Global 
partitioning of $\mathrm{NO}_{\mathrm{x}}$ sources using satellite observations: Relative roles of fossil fuel combustion, biomass burning and soil emissions, Faraday Disc., 130, 407-423, 2005.

Jacob, D. J., Logan, J. A., Gardner, G. M., Yevich, R. M., Spivakovsky, C. M., Wofsy, S. C., Sillman, S., and Prather, M. J.: Factors regulating ozone over the United States and its export to the global atmosphere, J. Geophys. Res., 98, 14 817-14 826, 1993.

Jacob D. J., Heikes, B. G., Fan, S.-M., Logan, J. A., Mauzerall, D. L., Bradshaw, J. D., Singh, H. B., Gregory, G. L., Talbot, R. W., Blake, D. R., and Sachse, G. W.: Origin of ozone and $\mathrm{NO}_{\mathrm{x}}$ in the tropical troposphere: A photochemical analysis of aircraft observations over the South Atlantic basin, J. Geophys. Res., 101, 24 235-24 250, 1996.

Jacob, D. J., Logan, J. A., and Murti, P. P.: Effect of rising emissions on surface ozone in the United States, Geophys. Res. Lett., 26, 2175-2178, 1999.

Jaffe, D. A., Anderson, T., Covert, D., Trost, B., Danielson, J., Simpson, W., Blake, D., Harris, J., and Streets, D.: Observations of ozone and related species in the northeast Pacific during the PHOBEA campaigns: 1 . Ground-based observations as Cheeka Peak, J. Geophys. Res., 106, 7449-7461, 2001.

Jaffe, D., Price, H., Parrish, D. D., Goldstein, A., and Harris, J.: Increasing background ozone during spring on the west coast of North America, Geophys. Res. Lett., 30(12), 1613, doi:10.1029/2003GL017024, 2003.

Jaffe, D., Prestbo, E., Swartzendruber, P., Weiss-Penzias, P., Kato, S., Takami, A., Hatakeyama, S., and Kajii, Y.: Export of atmospheric mercury from Asia, Atmos. Environ., 39, 3029-3038, 2005.

Jaffe, D. A. and Ray, J.: Increase in surface ozone at rural sites in the western US, Atmos. Environ., 41, 5452-5463, 2007.

Jaffe, D. A., Thornton, J., Wolfe, G., Reidmiller, D., Fischer, E. V., Jacob, D. J., Zhang, L., Cohen, R., Singh, H., Weinheimer, A., and Flocke, F.: Can we detect an influence over North America from increasing Asian $\mathrm{NO}_{\mathrm{x}}$ emissions?, Eos Trans. AGU, 88(52), Fall Meet. Suppl., Abstract A51E-04, 2007.

Kiley, C. M. and Fuelberg, H. E.: An examination of summertime cyclone transport processesduring Intercontinental Chemical Transport Experiment (INTEX-A), J. Geophys. Res., 111, D24S06, doi:10.1029/2006JD007115, 2006.

Kotchenruther, R. A., Jaffe, D. A., and Jaeglé, L.: Ozone Photochemistry and the Role of PAN in the Springtime Northeastern Pacific Troposphere: Results from the PHOBEA Campaign. J. Geophys. Res. 106, 28 731-28 741, 2001.

Latto, A. and Fuelberg, H.: Quasi-Lagrangian Chemical Sampling during INTEX-B, Eos Trans. AGU, 88(52), Fall Meet. Suppl., Abstract A42A-08, 2007.

Levelt, P. F., van den Oord, G. H. J., Dobber, M. R., Mälkki, A., Visser, H., de Vries, J., Stammes, P., Lundell, J. O. V., and Saari, H.: The Ozone Monitoring Instrument, IEEE T. Geosci. Remote, 44(5), 1093-1101, 2006.

Li, Q., Jacob, D. J., Bey, I., Palmer, P. I., Duncan, B. N., Field, B. D., Martin, R. V., Fiore, A. M., Yantosca, R. M., Parrish, D. D., Simmonds, P. G., and Oltmans, S. J.: Transatlantic transport of pollution and its effects on surface ozone in Europe and North America, J. Geophys. Res., 107(D13), 4166, doi:10.1029/2001JD001422, 2002.

Liang, Q., Jaeglé, L., Jaffe, D. A., Weiss-Penzias, P., Heckman,
A., and Snow, J. A.: Long-range transport of Asian pollution to the northeast Pacific: Seasonal variations and transport pathways of carbon monoxide, J. Geophys. Res., 109, D23S07, doi:10.1029/2003JD004402, 2004.

Liang, Q., Jaeglé, L., and Wallace, J. M.: Meteorological indices for Asian outflow and transpacific transport on daily to interannual timescales, J. Geophys. Res., 110, D18308, doi:10.1029/2005JD005788, 2005.

Liang, Q., Jaeglé, L., Hudman, R. C., Turquety, S., Jacob, D. J., Avery, M. A., Browell, E. V., Sachse, G. W., Blake, D. R., Brune, W., Ren, X., Cohen, R. C., Dibb, J. E., Fried, A., Fuelberg, H., Porter, M., Heikes, B. G., Huey, G., Singh, H. B., and Wennberg, P. O.: Summertime influence of Asian pollution in the free troposphere over North America, J. Geophys. Res., 112, D12S11, doi:10.1029/2006JD007919, 2007.

Liu, S. C., Trainer, M., Fehsenfeld, F. C., Parrish, D. D., Williams, E. J., Fahey, D. W., Gubler, G., and Murphy, P. C.: Ozone production in the rural troposphere and the implications for regional and global ozone distributions, J. Geophys. Res., 92, 4191-4207, 1987.

Liu, H., Jacob, D. J., Bey, I., Yantosca, R. M., Duncan, B. N., and Sachse, G. W.: Transport pathways for Asian pollution outflow over the Pacific: Interannual and seasonal variations, J. Geophys. Res., 108(D20), 8786, doi:10.1029/2002JD003102, 2003.

Liu, J. and Mauzerall, D. L.: Estimating the average time for intercontinental transport of air pollutants, Geophys. Res. Lett., 32, L11814, doi:10.1029/2005GL022619, 2005.

Luo, M., Rinsland, C. P., Rodgers, C. D., Logan, J. A., Worden, H., Kulawik, S., Eldering, A., Goldman, A., Shephard, M. W., Gunson, M., and Lampel, M.: Carbon monoxide measurements by TES and MOPITT - the influence of a priori data and instrument characteristics on nadir atmospheric species retrievals, J. Geophys. Res., 112, D09303, doi:101029/2006JD007663, 2007a.

Luo, M., Rinsland, C., Fisher, B., Sachse, G., Diskin, G., Logan, J., Worden, H., Kulawik, S., Osterman, G., Eldering, A., Herman R., and Shephard, M.: TES carbon monoxide validation with DACOM aircraft measurements during INTEX-B 2006, J. Geophys. Res., 112, D24S48, doi:10.1029/2007JD008803, 2007b.

Martin, B. D., Fuelberg, H. E., Blake, N. J., Crawford, J. H., Logan, J. A., Blake, D. R., and Sachse, G. W.: Long range transport of Asian outflow to the equatorial Pacific, J. Geophys. Res., 108(D2), 8322, doi:10.1029/2001JD001418, 2003.

Martin, R. V., Jacob, D. J., Chance, K., Kurosu, T. P., Palmer, P. I., and Evans, M. J.: Global inventory of nitrogen oxide emissions constrained by space-based observations of $\mathrm{NO}_{2}$ columns, J. Geophys. Res., 108(D17), 4537, doi:10.1029/2003JD003453, 2003.

Martin, R. V., Sioris, C. E., Chance, K., Ryerson, T. B., Bertram, T. H., Wooldridge, P. J., Cohen, R. C., Neuman, J. A., Swanson, A., and Flocke, F. M.: Evaluation of space-based constraints on global nitrogen oxide emissions with regional aircraft measurements over and downwind of eastern North America, J. Geophys. Res., 111, D15308, doi:10.1029/2005JD006680, 2006.

McLinden, C. A., Olsen, S. C., Hannegan, B., Wild, O., Prather, M. J., and Sundet, J.: Stratospheric ozone in 3-D models: A simple chemistry and the cross-tropopause flux, J. Geophys. Res., 105(D11), 14 653-14 666, 2000.

McMillan, W. W., Barnet, C., Strow, L., Chahine, M., Warner, J., McCourt, M., Novelli, P., Korontzi, S., Maddy, E., and Datta, 
S.: Daily global maps of carbon monoxide from NASA's Atmospheric Infrared Sounder, Geophys. Res. Lett., 32, L11801, doi:10.1029/2004GL021821, 2005.

McMillan, W. W., Warner, J. X., Comer, M. M., et al.: AIRS views of transport from 12-22 July 2004 Alaskan/Canadian fires: Correlation of AIRS CO and MODIS AOD with forward trajectories and comparison of AIRS CO retrievals with DC-8 in situ measurements during INTEX-A/ICARTT, J. Geophys. Res., in review, 2008.

Nassar, R., Logan, J. A., Worden, H. M., et al.: Validation of tropospheric emissions spectrometer (TES) nadir ozone profiles using ozonesonde measurements, J. Geophys. Res., 113, in press, doi:10.1029/2007JD008819, 2008.

Nowak, J. B., Parrish, D. D., Neuman, J. A., Holloway, J. S., Cooper, O. R., Ryerson, T. B., Nicks Jr., D. K., Flocke, F., Roberts, J. M., Atlas, E., de Gouw, J. A., Donnelly, S., Dunlea, E., Hübler, G., Huey, L. G., Schauffler, S., Tanner, D. J., Warneke, C., and Fehsenfeld, F. C.: Gas-phase chemical characteristics of Asian emission plumes observed during ITCT 2K2 over the eastern North Pacific Ocean, J. Geophys. Res., 109, D23S19, doi:10.1029/2003JD004488, 2004.

Ohara, T., Akimoto, H., Kurokawa, J., Horii, N., Yamaji, K., Yan, X., and Hayasaka, T.: An Asian emission inventory of anthropogenic emission sources for the period 1980-2020, Atmos. Chem. Phys., 7, 4419-4444, 2007,

http://www.atmos-chem-phys.net/7/4419/2007/.

Olson, J. R., Crawford, J. H., Chen, G., Brune, W. H., Faloona, I. C., Tan, D., Harder, H., and Martinez, M.: A reevaluation of airborne $\mathrm{HO}_{\mathrm{x}}$ observations from NASA field campaigns, J. Geophys. Res., 111, D10301, doi:10.1029/2005JD006617, 2006.

Park, R. J., Jacob, D. J., Field, B. D., Yantosca, R. M., and Chin, M.: Natural and trans-boundary pollution influences on sulfate-nitrate-ammonium aerosols in the United States: Implications for policy, J. Geophys. Res., 109, D15204, doi:10.1029/2003JD004473, 2004.

Parrish, D. D., Holloway, J. S., Trainer, M., Murphy, P. C., Fehsenfeld, F. C., and Forbes, G. L.: Export of North America ozone pollution to the North Atlantic Ocean, Science, 259, 1436-1439, 1993.

Pierce, R. B., Al-Saadi, J. A., Schaack, T., Lenzen, A., Zapotocny, T., Johnson, D., Kittaka, C., Buker, M., Hitchman, M. H., Tripoli, G., Fairlie, T. D., Olson, J. R., Natarajan, M., Crawford, J., Fishman, J., Avery, M., Browell, E. V., Creilson, J., Kondo, Y., and Sandholm, S. T.: Regional Air Quality Modeling System (RAQMS) predictions of the tropospheric ozone budget over east Asia, J. Geophys. Res., 108(D21), 8825, doi:10.1029/2002JD003176, 2003.

Pickering, K. E., Wang, Y. S., Tao, W. K., Price, C., and Muller, J. F.: Vertical distributions of lightning $\mathrm{NO}_{\mathrm{x}}$ for use in regional and global chemical transport models, J. Geophys. Res., 103, $31203-$ $31216,1998$.

Prather, M. J. and Ehhalt, D.: Chapter 4: Atmospheric Chemistry and Greenhouse Gases, in Climate Change 2001: The Science of Climate Change, Intergovernmental Panel on Climate Change, Cambridge University Press, 260-263, 2001.

Price, C. and Rind, D.: A simple lightning parameterization for calculating global lightning distributions, J. Geophys. Res., 97, 9919-9933, 1992.

Price, H. U., Jaffe, D. A., Cooper, O. R., and Doskey, P. V.: Pho- tochemistry, ozone production, and dilution during long-range transport episodes from Eurasia to the northwest United States, J. Geophys. Res., 109, D23S13, doi:10.1029/2003JD004400, 2004.

Reidmiller, D. R., Jaffe, D. A., Chand, D., Strode, S., Swartzendruber, P., Wolfe, G. M., and Thornton, J. A.: Interannual variability of long-range transport as seen at the Mt. Bachelor Observatory, Atmos. Chem. Phys. Discuss., 8, 16335-16379, 2008, http://www.atmos-chem-phys-discuss.net/8/16335/2008/.

Ren, X., Mao, J., Chen, Z., Brune, W., Olson, J., Crawford, J., Chen, G.: $\mathrm{HO}_{\mathrm{x}}$ Chemistry and Ozone Production During INTEX-B, Eos Trans. AGU, 88(52), Fall Meet. Suppl., Abstract A42A-04, 2007.

Richards, N. A. D., Osterman, G. B., Browell, E. V., Hair, J. W., Avery M., and Li, Q.: Validation of Tropospheric Emission Spectrometer (TES) Ozone Profiles with Aircraft Observations During INTEX-B, J. Geophys. Res., 113, D16S29, doi:10.1029/2007JD008815 2008.

Richter, A., Burrows, J. P., Nüß, H., Granier, C., and Niemeier, U.: Increase in tropospheric nitrogen dioxide levels over China observed from space, Nature, 437, 129-132, 2005.

Staudt, A. C., Jacob, D. J., Logan, J. A., Bachiochi, D., Krishnamurti, T. N., and Sachse, G. W.: Continental sources, transoceanic transport, and interhemispheric exchange of carbon monoxide over the Pacific, J. Geophys. Res., 106, 32 571-32 590, 2001.

Stohl, A., Eckhardt, S., Forster, C., James, P., and Spichtinger, N.: On the pathways and timescales of intercontinental air pollution transport, J. Geophys. Res., 107(D23), 4684, doi:10.1029/2001JD001396, 2002.

Streets, D. G., Bond, T. C., Carmichael, G. R., Fernandes, S. D., Fu, Q., He, D., Klimont, Z., Nelson, S. M., Tsai, N. Y., Wang, M. Q., Woo, J.-H., and Yarber, K. F.: An inventory of gaseous and primary aerosol emissions in Asia in the year 2000, J. Geophys. Res., 108(D21), 8809, doi:10.1029/2002JD003093, 2003.

Streets, D. G., Zhang, Q., Wang, L., He, K., Hao, J., Wu, Y., Tang, Y., and Carmichael, G. R.: Revisiting China's CO emissions after TRACE-P: Synthesis of inventories, atmospheric modeling, and observations, J. Geophys. Res., 111, D14306, doi:10.1029/2006JD007118, 2006.

Sudo, K. and Akimoto, H.: Global source attribution of tropospheric ozone: Long-range transport from various source regions, J. Geophys. Res., 112, D12302, doi:10.1029/2006JD007992, 2007.

Thompson, A. M., Pickering, K. E., Dickerson, R. R., Ellis, W. G., Jacob, D. J., Scala, J. R., Tao, W. K., McNamara, D. P., and Simpson, J.: Convective transport over the central United States and its role in regional $\mathrm{CO}$ and ozone budgets, J. Geophys. Res., 99(D9), 18 703-18711, 1994.

Thompson, A. M., Pickering, K. E., McNamara, D. P., Schoeberl, M. R., Hudson, R. D., Kim, J.-H., Browell, E. V., Kirchhoff, V. W. J. H., and Nganga, D.: Where did tropospheric ozone over southern Africa and the tropical Atlantic come from in October 1992? Insights from TOMS, GTE/TRACE-A and SAFARI-92, J. Geophys. Res., 101, 24 251-24 278, 1996.

Thompson, A. M., Yorks, J. E., Miller, S. K., Witte, J. C., Dougherty, K. M., Morris, G. A., Baumgardner, D., Ladino, L., and Rappenglück, B.: Tropospheric ozone sources and wave activity over Mexico City and Houston during 
MILAGRO/Intercontinental Transport Experiment (INTEX-B) Ozonesonde Network Study, 2006 (IONS-06), Atmos. Chem. Phys., 8, 5113-5125, 2008, http://www.atmos-chem-phys.net/8/5113/2008/.

van der A, R. J., Peters, D. H. M. U., Eskes, H., Boersma, K. F., Van Roozendael, M., De Smedt, I., and Kelder, H. M.: Detection of the trend and seasonal variation in tropospheric $\mathrm{NO}_{2}$ over China, J. Geophys. Res., 111, D12317, doi:10.1029/2005JD006594, 2006.

van der Werf, G. R., Randerson, J. T., Giglio, L., Collatz, G. J., Kasibhatla, P. S., and Arellano Jr., A. F.: Interannual variability in global biomass burning emissions from 1997 to 2004, Atmos. Chem. Phys., 6, 3423-3441, 2006, http://www.atmos-chem-phys.net/6/3423/2006/.

Venables, W. N. and Ripley, B. D.: Modern Applied Statistics with S-PLUS, 3rd ed., Springer-Verlag, New York, p. 501, 1999.

Wang, Y., Jacob, D. J., and Logan, J. A.: Global simulation of tropospheric $\mathrm{O}_{3}-\mathrm{NO}_{\mathrm{x}}$-hydrocarbon chemistry 1 . Model formulation, J. Geophys. Res., 103(D9), 10713-10726, 1998a.

Wang, Y., Jacob, D. J., and Logan, J. A.: Global simulation of tropospheric $\mathrm{O}_{3}-\mathrm{NO}_{\mathrm{X}}$-hydrocarbon chemistry, 3. Origin of tropospheric ozone and effects of non-methane hydrocarbons, J. Geophys. Res., 103/D9, 10757-10 768, 1998b.

Wang, Y. X., McElroy, M. B., Martin, R. V., Streets, D. G., Zhang, Q., and Fu, T.-M.: Seasonal variability of $\mathrm{NO}_{\mathrm{x}}$ emissions over east China constrained by satellite observations: Implications for combustion and microbial sources, J. Geophys. Res., 112, D06301, doi:10.1029/2006JD007538, 2007.

Warner, J., Comer, M. M., Barnet, C. D., McMillan, W. W., Wolf, W., Maddy, E., and Sachse, G.: A comparison of satellite tropospheric carbon monoxide measurements from AIRS and MOPITT during INTEX-A, J. Geophys. Res., 112, D12S17, doi:10.1029/2006JD007925, 2007.

Weiss-Penzias, P., Jaffe, D. A., Jaeglé, L., and Liang, Q.: Influence of long-range-transported pollution on the annual and diurnal cycles of carbon monoxide and ozone at Cheeka Peak Observatory, J. Geophys. Res., 109, D23S14, doi:10.1029/2004JD004505, 2004.

Weiss-Penzias, P., Jaffe, D. A., Swartzendruber, P., Dennison, J. B., Chand, D., Hafner, W., and Prestbo, E.: Observations of Asian air pollution in the free troposphere at Mount Bachelor Observatory during the spring of 2004, J. Geophys. Res., 111, D10304, doi:10.1029/2005JD006522, 2006.
Weiss-Penzias, P., Jaffe, D. A., Swartzendruber, P., Hafner, W., Chand, D., and Prestbo, E.: Quantifying Asian and biomass burning sources of mercury using the $\mathrm{Hg} / \mathrm{CO}$ ratio in pollution plumes observed at the Mount Bachelor Observatory, Atmos. Envir., 41, doi:10.1016/j.atmosenv.2007.01.058, 2007.

Wild, O. and Akimoto, H.: Intercontinental transport of ozone and its precursors in a three-dimensional global CTM, J. Geophys. Res., 106, 27 729-27 744, 2001.

Wolfe, G. M., Thornton, J. A., McNeill, V. F., Jaffe, D. A., Reidmiller, D., Chand, D., Smith, J., Swartzendruber, P., Flocke, F., and Zheng, W.: Influence of trans-Pacific pollution transport on acyl peroxy nitrate abundances and speciation at Mount Bachelor Observatory during INTEX-B, Atmos. Chem. Phys., 7, 53095325, 2007, http://www.atmos-chem-phys.net/7/5309/2007/.

Worden, J., Kulawik, S. S., Shephard, M. W., Clough, S. A., Worden, H., Bowman, K., and Goldman, A.: Predicted errors of tropospheric emission spectrometer nadir retrievals from spectral window selection, J. Geophys. Res., 109, D09308, doi:10.1029/2004JD004522, 2004.

Yienger, J. J. and Levy II, H.: Empirical model of global soil biogenic $\mathrm{NO}_{\mathrm{x}}$ emissions, J. Geophys. Res., 100, 11447-11464, 1995.

Yienger, J. J., Galanter, M., Holloway, T. A., Phadnis, M. J., Guttikunda, S. K., Carmichael, G. R., Moxim, W. J., and Levy, H.: The episodic nature of air pollution transport from Asia to North America, J. Geophys. Res., 105, 26 931-26 945, 2000.

Zhang, L., Jacob, D. J., Bowman, K. W., Logan, J. A., Turquety, S., Hudman, R. C., Li, Q., Beer, R., Worden, H. M., Worden, J. R., Rinsland, C. P., Kulawik, S. S., Lampel, M. C., Shephard, M. W., Fisher, B. M., Eldering, A., and Avery, M. A.: Continental outflow of ozone pollution as determined by $\mathrm{O}_{3}-\mathrm{CO}$ correlations from the TES satellite instrument, Geophys. Res. Lett., 33, L18804, doi:10.1029/2006GL026399, 2006.

Zhang, Q., Streets, D. G., He, K., Wang, Y., Richter, A., Burrows, J. P., Uno, I., Jang, C. J., Chen, D., Yao, Z., and Lei, Y.: $\mathrm{NO}_{\mathrm{X}}$ emission trends for China, 1995-2004: The view from the ground and the view from space, J. Geophys. Res., 112, D22306, doi:10.1029/2007JD008684, 2007. 